\title{
Article
}

\section{The Federalist Dimension of Regulatory Takings Jurisprudence}

\author{
Stewart E. Sterk ${ }^{\dagger}$
}

\section{CONTENTS}

INTRODUCTION

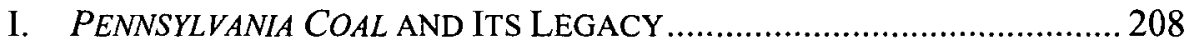

A. Pennsylvania Coal as a Limit on Regulatory Takings ................ 208

B. Pennsylvania Coal as a Protection Against Legislative Change ... 210

C. Pennsylvania Coal and the Increased Importance of State Law ....211

D. Regulatory Takings, State Law, and Takings Scholarship........... 215

II. TAKINGS IN A FEDERAL SYSTEM: STATE LAW AND THE SUPREME COURT OF THE UNITED STATES........................................................ 218

A. State Law and the Supreme Court in the Enforcement of Federal Constitutional Rights................................................... 218

B. State Law and Takings Adjudication .......................................... 222

C. Guidance, Uniformity, and the Limited Value of Supreme Court Review in Takings Litigation ............................................ 226

1. Complexity...............................................................226

$\dagger$ Mack Professor of Law, Benjamin N. Cardozo School of Law, Yeshiva University. I would like to thank Richard Bierschbach, Richard Epstein, Myriam Gilles, Melanie Leslie, John McGinnis, Thomas Merrill, Kevin Stack, and Ed Stein for their invaluable comments on earlier drafts. Jeremy Goldman, Jody Saltzman, and Julia Zuckerman provided helpful research assistance. 


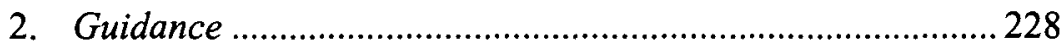

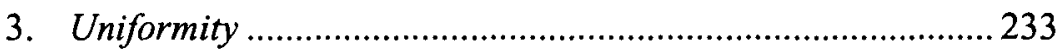

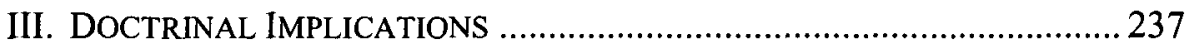

A. Ripeness and the Role of Inferior Federal Courts ......................238

B. Categorical Rules .................................................................. 243

1. Availability of Money Damages for Takings ........................ 244

2. Exactions and the Rough-Proportionality Requirement .......246

3. Denial of All Beneficial Use ............................................... 248

4. Permanent Physical Occupations....................................... 248

5. Impact of Land Transfer on Right To Raise

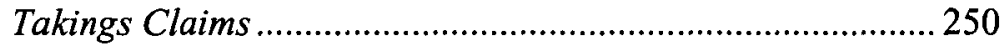

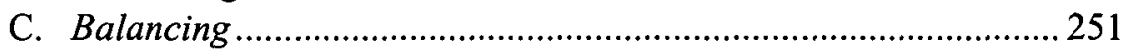

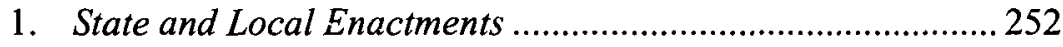

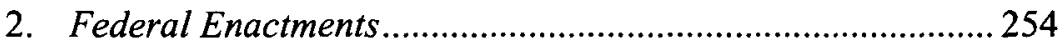

IV. THE STATES AS GUARDIANS OF PROPERTY RIGHTS ....................... 257

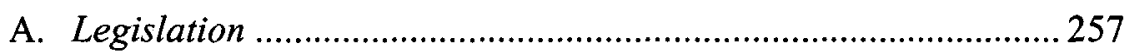

1. Property Rights Legislation..............................................257

2. Statutory Limits on Moratoria ........................................... 259

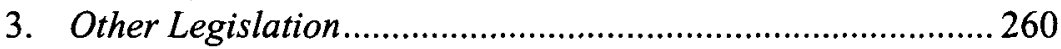

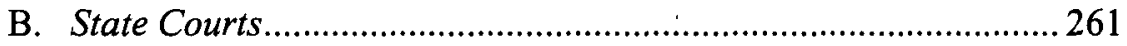

1. Developing State Law Doctrines To Control Local

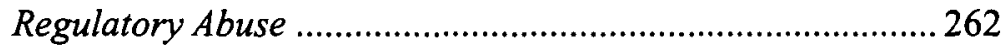

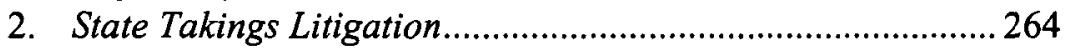

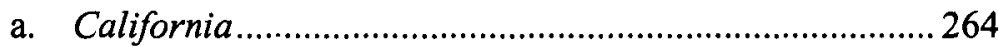

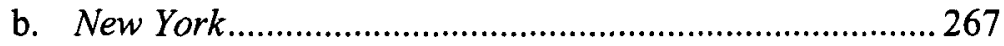

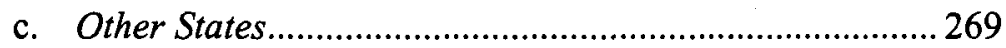

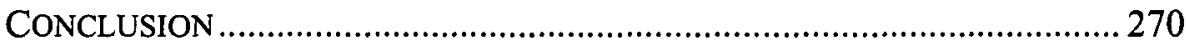




\section{INTRODUCTION}

Conventional wisdom teaches that the Supreme Court's takings doctrine is a muddle. ' And the Supreme Court's opinions have given conventional wisdom considerable ammunition. A landowner is entitled to full compensation whenever she can prove that a regulation has deprived her parcel of one hundred percent of its value; ${ }^{2}$ if she can only prove a loss of ninety-five percent, she is apparently relegated to a balancing test that is unlikely to generate any redress at all. ${ }^{3}$ The government must compensate the landowner when it requires her to permit installation of a tiny cable box on her roof, ${ }^{4}$ but not when it denies her the right to build a multimilliondollar office building. ${ }^{5}$ These conclusions do not appear to fit neatly into a coherent analytical framework.

Appearances, however, are deceiving. The "property" protected by the Takings Clause is defined not by a single sovereign, but by the legislative enactments and judicial pronouncements of fifty separate states. As a result, federalism concerns-underappreciated in the takings literature-do and should play an important role in shaping the Court's takings doctrine. In particular, these concerns make it inappropriate for the Court to use the Takings Clause as a vehicle for articulating a comprehensive theory of the limits on government power to regulate land.

The Supreme Court cannot and does not provide the primary protection against overly burdensome land use regulations. Whenever the Supreme Court provides a federal constitutional standard against which state acts must be measured, it must inevitably leave application of that standard to other decisionmakers. The sheer volume of enactments prevents the Court from taking the leading role in enforcing constitutional standards. As a

1. For representative expressions of the conventional wisdom, see Abraham Bell \& Gideon Parchomovsky, Takings Reassessed, 87 VA. L. REV. 277, 278 (2001) ("Takings jurisprudence is replete with inconsistent distinctions that provide scant guidance for courts and policymakers."); Andrea L. Peterson, The Takings Clause: In Search of Underlying Principles: Part I- a Critique of Current Takings Clause Doctrine, 77 CAL. L. REV. 1301, 1304 (1989) ("[I]t is difficult to imagine a body of case law in greater doctrinal and conceptual disarray."); and Jeanne L. Schroeder, Never Jam To-day: On the Impossibility of Takings Jurisprudence, 84 GEO. L.J. 1531, 1531 (1996) (asserting that takings jurisprudence is a "top contender for the dubious title of 'most incoherent area of American law"').

2. Lucas v. S.C. Coastal Council, 505 U.S. 1003 (1992).

3. Id. at 1019 n.8.; see also Tahoe-Sierra Pres. Council v. Tahoe Reg'l Planning Agency, 535 U.S. 302, 330 (2002); The Supreme Court, 2001 Term-Leading Cases, 116 HARV. L. REV. 200, 331 (2002) ("Lucas is easy to sidestep-stop just short of taking 100\%-and governments can easily take advantage of Tahoe-Sierra by extending temporary moratoria repeatedly." (footnote omitted)).

4. Loretto v. Teleprompter Manhattan CATV Corp., 458 U.S. 419 (1982).

5. Penn Cent. Transp. Co. v. City of New York, 438 U.S. 104 (1978). 
result, state courts, lower federal courts, legislatures, and administrative agencies must play a role in fleshing out the Court's pronouncements.

Takings cases, however, provide a challenge different in kind from those raised by other constitutional provisions. For example, the First Amendment and the Equal Protection Clause provide federal constitutional standards against which state and local enactments are to be measured. Consider Locke v. Davey, ${ }^{6}$ in which the Supreme Court rejected free exercise and equal protection challenges to a Washington statute that excluded students pursuing devotional theology degrees from a merit scholarship program. ${ }^{7}$ The Court examined the text, history, and operation of the statute (and the state constitutional provision on which it was based) against the Free Exercise Clause's constitutional baseline-the state may not display animus toward religion ${ }^{8}$-and against the Equal Protection Clause's constitutional baseline-the state must have a rational basis to support discrimination. ${ }^{9}$

By contrast, the Takings Clause furnishes no comparable constitutional baseline. The Takings Clause protects primarily against change in background state law. As a result, the constitutional protection available to a landowner depends heavily on background principles of state law in effect before the challenged regulation was enacted. A regulation that constitutes an unconstitutional taking in Houston could pass constitutional muster if enacted in New York. Because the constitutional standard against which any regulation is measured must itself incorporate background state law, the Supreme Court cannot develop a comprehensive national takings standard.

Moreover, a comprehensive national takings standard is unnecessary. State law and state courts provide the primary protection against overly burdensome land use regulations. Most (although not all) land use regulation is conducted at the local level. State legislatures and state courts are insulated from many of the pressures that face local regulators and are consequently in a position to police abusive practices. The Supreme Court's Penn Central balancing test, ${ }^{10}$ which, as a matter of practice, results in deference to the state courts, recognizes the institutional advantages state courts enjoy in constraining regulatory abuse. To be sure, state courts have had a somewhat checkered record in applying the Takings Clause, but that does not distinguish them from the Supreme Court itself.

6. 124 S. Ct. 1307 (2004).

7. The statute was enacted pursuant to the state's constitution, which provides that "[n]o public money or property shall be appropriated for or applied to any religious worship, exercise or instruction, or the support of any religious establishment." WASH. CONST. art. I, $\S 11$.

8. Davey, 124 S. Ct. at 1315.

9. Id. at 1312 n.3.

10. Penn Cent., 438 U.S. at 129 (identifying factors relevant to takings analyses). 
And a number of state courts have demonstrated the capacity to protect landowners against overzealous regulation.

The primary role state law must play in policing takings does not, however, make the Supreme Court irrelevant. First, the Supreme Court might articulate categorical rules that address difficulties cutting across state law. The Court has in fact taken that approach: Two examples are the Lucas rule requiring compensation for regulations that deprive a landowner of one hundred percent of land value ${ }^{11}$ and the Nollan-Dolan rule requiring a causal nexus between a development's impact and an exaction required by the municipality as a condition of development. ${ }^{12}$ Second, to recognize the primacy of state law issues in takings cases, the Court could develop a set of jurisdictional rules limiting access to the Supreme Court and, for that matter, the federal courts generally. The Court has taken that approach as well. ${ }^{13}$ Finally, the Supreme Court could remain active in cases involving federal takings, where state legislatures and courts are ill equipped to police federal regulators. Here, too, the Court's actions reflect its institutional role. $^{14}$

This Article, then, focuses on the ways in which federalism concerns (together with related institutional concerns) shape takings jurisprudence. Part I demonstrates that Justice Holmes's opinion in Pennsylvania Coal Co. v. Mahon ${ }^{15}$-often recognized as the first to establish that regulation could effect an unconstitutional "taking"-is equally important for establishing that state law serves as the foundation for evaluating takings claims. Part II explains that the primacy of state law in evaluating takings claims limits the Supreme Court's capacity to develop a comprehensive takings jurisprudence and suggests a greater role for the states in monitoring local regulation. Part III serves as a descriptive counterpart to the normative discussion in Part II, arguing that existing doctrine reflects the Court's limited capacity and effectively delegates to the states the primary responsibility for policing regulation of property rights. Part IV explores the ways in which the states have acted-both legislatively and judiciallyto implement the core mission of the Takings Clause: protection of property rights against unforeseeable regulatory change.

11. Lucas v. S.C. Coastal Council, 505 U.S. 1003, 1015-17 (1992).

12. Dolan v. City of Tigard, 512 U.S. 374, 385-91 (1994); Nollan v. Cal. Coastal Comm'n, 483 U.S. $825,837-38$ (1987).

13. See, e.g., MacDonald, Sommer \& Frates v. County of Yolo, 477 U.S. 340 (1986); Williamson County Reg'l Planning Comm'n v. Hamilton Bank of Johnson City, 473 U.S. 172 (1985).

14. See infra Subsection III.C.2.

15. 260 U.S. 393 (1922). 


\section{PENNSYlVANIA COAL AND ITS LEGACY}

Pennsylvania Coal Co. v. Mahon ${ }^{16}$ presented the Supreme Court with a simple set of facts. In 1878 , Pennsylvania Coal executed a deed conveying rights in the surface of a parcel of land. ${ }^{17}$ In express terms, the deed reserved to Pennsylvania Coal the right to remove coal under the surface. By the terms of the deed, the grantee assumed the risk of subsurface coal mining and waived all claims for damages that might arise from such mining. ${ }^{18}$

In 1921, the Pennsylvania legislature enacted the Kohler Act, which prohibited mining of anthracite coal in a way that would cause the subsidence of a structure used for human habitation. Successors in interest to the 1878 grantee, relying on the new statute, filed a bill in equity to enjoin the coal company from mining coal in a way that would cause subsidence of their house and the surface of their land. In effect, the homeowners sued to enforce the very rights their predecessors had waived by the terms of the 1878 deed. The Pennsylvania Court of Common Pleas denied injunctive relief, holding that the Kohler Act, if applied to the case, would be unconstitutional. The Pennsylvania Supreme Court reversed, holding that the statute was a legitimate exercise of the police power. The United States Supreme Court reversed and held the Act unconstitutional. ${ }^{19}$

\section{A. Pennsylvania Coal as a Limit on Regulatory Takings}

Pennsylvania Coal has become a staple in law school casebooks as the first "regulatory takings" case. ${ }^{20}$ That is, before Pennsylvania Coal, the Court had invoked constitutional provisions protecting property rights only when government action physically interfered with a landowner's use of the land. ${ }^{21}$ Early cases focused on whether the landowner had been

16. Id.

17. Id. at 412 .

18. Id.

19. Id. at 412,414 .

20. See, e.g., A. James CASNer ET AL., CASES AND TeXt ON Property 1113 (4th ed. 2000); John E. CRIBbet ET Al., Property: CASES AND MATERIAls 745 (8th ed. 2002); Jesse DUKEMINIER \& JAMES E. KRIER, PROPERTY 1140 (5th ed. 2002).

21. As Justice Scalia put it in Lucas, "Prior to Justice Holmes's exposition in Pennsylvania Coal Co. v. Mahon, it was generally thought that the Takings Clause reached only a 'direct appropriation' of property or the functional equivalent of a 'practical ouster of [the owner's] possession." 505 U.S. 1003, 1014 (1992) (alteration in original) (citations omitted); see, e.g., Pumpelly v. Green Bay Co., 80 U.S. (13 Wall.) 166 (1872) (finding that state authorization of a dam that resulted in the overflowing of the landowner's land constituted a taking). Pumpelly involved construction of the Wisconsin Constitution because the case reached the Supreme Court on appeal from a Wisconsin federal court. The Supreme Court was sitting, in effect, as a Wisconsin state court. At the time of Pumpelly-and at the time of Pennsylvania Coal - the Court 
practically ousted from the land, ${ }^{22}$ but the Court later came to award compensation for government actions that would have been tortious if committed by a private citizen. ${ }^{23}$ In these cases, the government was treated as if it had exercised its eminent domain power, requiring compensation to the injured landowner. By contrast, regulation of landowner activities was said to be an exercise of the government's police power and was, for that reason, exempt from any obligation to compensate. ${ }^{24}$ Mugler v. Kansas ${ }^{25}$ was the leading case. By constitutional amendment, the State of Kansas prohibited the sale and manufacture of intoxicating liquors within the state. When the state sought to enforce the prohibition against a brewery that had been in operation before enactment of the amendment, the brewery contended that application of the prohibition to preexisting breweries would constitute a deprivation of its property without due process of law. In an opinion by Justice Harlan, the Supreme Court held that no compensation was due the brewery, relying on the categorical distinction between the eminent domain power and the police power. ${ }^{26}$

had not interpreted the Fifth Amendment's Takings Clause to apply to actions taken by the states. Instead, the Court had construed the Fourteenth Amendment's Due Process Clause to require compensation when the states took private property for public uses. See Robert Brauneis, "The Foundation of Our 'Regulatory Takings' Jurisprudence": The Myth and Meaning of Justice Holmes's Opinion in Pennsylvania Coal Co. v. Mahon, 106 YALE L.J. 613, 667-68 \& n.250 (1996) (citing Chi., Burlington \& Quincy R.R. v. City of Chicago, 166 U.S. 226 (1897)).

For a discussion of the early "physicalist" view of the Takings Clause, see William Michael Treanor, The Original Understanding of the Takings Clause and the Political Process, 95 COLUM. L. REV. 782, 792-99 (1995).

22. See, e.g., Transp. Co. v. Chicago, 99 U.S. 635,642 (1879).

23. See, e.g., Richards v. Wash. Terminal Co., 233 U.S. 546 (1914) (holding that compensation would be required if legislation forced a railroad to build in such a way as to constitute a private nuisance); Muhlker v. N.Y. \& Harlem R.R., 197 U.S. 544 (1905) (requiring compensation when a city required a railroad to run trains on an elevated railway, depriving abutting owners of easement of light and air). See generally William Michael Treanor, Jam for Justice Holmes: Reassessing the Significance of Mahon, 86 GEO. L.J. 813, 839-40 (1998) (reviewing eminent domain decisions before Pennsylvania Coal).

24. Thus, in Mugler v. Kansas, 123 U.S. 623 (1887), the Court drew a categorical distinction between cases like Pumpelly, which involved exercise of the eminent domain power, and regulation cases, which involved the police power: "The question in Pumpelly v. Green Bay Company arose under the State's power of eminent domain; while the question now before us arises under what are, strictly, the police powers of the State, exerted for the protection of the health, morals, and safety of the people." Id. at 668 . The Court went on to explain its view of the difference:

The exercise of the police power by the destruction of property which is itself a public nuisance, or the prohibition of its use in a particular way, whereby its value becomes depreciated, is very different from taking property for public use, or from depriving a person of his property without due process of law. In the one case, a nuisance only is abated; in the other, unoffending property is taken away from an innocent owner. Id. at 669 .

25. 123 U.S. 623.

26. Id. at 669 . 
In Pennsylvania Coal, the Court's majority abandoned Mugler's sharp, categorical distinction between the eminent domain and police powers. ${ }^{27}$ Justice Holmes blurred the distinction in an oft-quoted sentence: "The general rule at least is, that while property may be regulated to a certain extent, if regulation goes too far it will be recognized as a taking." Government power to regulate land use had thus become a matter of degree, generating the doctrinal uncertainty that has endured to the present day. ${ }^{29}$

\section{B. Pennsylvania Coal as a Protection Against Legislative Change}

Although most renowned for its rejection of the rigid categorical separation of regulations and takings, Pennsylvania Coal also established that the Constitution protects property rights against legislative change. First, Holmes emphasized that the Constitution prevents legislatures from following "the natural tendency of human nature" to expand use of the police power "more and more until at last private property disappears." The focus on change is even more apparent in one of the opinion's most quotable sentences: "We are in danger of forgetting that a strong public desire to improve the public condition is not enough to warrant achieving

27. See Pa. Coal Co. v. Mahon, 260 U.S. 393, 415 (1922). For the classic comparison between the philosophies of Harlan and Holmes on the takings issue, see Joseph L. Sax, Takings and the Police Power, 74 YALE L.J. 36, 38-46 (1964). William Treanor has argued persuasively that the pre-Pennsylvania Coal cases fell into three categories, not two. In particular, he points to challenges to rate regulations, in which the Court determined that the states could subject to rate regulation only those businesses "affected with a public interest" and could not deny the regulated business a reasonable rate of return. See Treanor, supra note 23, at 836-39.

28. Pa. Coal, 260 U.S. at 415.

29. See Treanor, supra note 21 , at 803 (noting that the prior categorical distinctions made it easy to determine when compensation was due, by contrast with the open-ended Pennsylvania Coal approach).

The categorical distinction between exercises of the eminent domain power and the police power remained significant for remedial purposes until the Supreme Court's decision in First English Evangelical Lutheran Church v. County of Los Angeles, 482 U.S. 304 (1987). Until that time, leading state courts had held that if a municipality had enacted a regulation, even if that regulation exceeded the scope of the police power, the landowner was entitled only to invalidation of the ordinance-not to compensation, even for the period between enactment of the ordinance and the time it was declared invalid. See, e.g., Agins v. City of Tiburon, 598 P.2d 25 (Cal. 1979), aff d, 447 U.S. 255 (1980); Fred F. French Investing Co. v. City of New York, 350 N.E.2d 381 (N.Y. 1976). See generally Stewart E. Sterk, Government Liability for Unconstitutional Land Use Regulation, 60 IND. L.J. 113, 118-23 (1984) (discussing analysis of California and New York courts in concluding that compensation was not available for unconstitutional regulations). First English rejected this approach, holding that a landowner is entitled to damages for temporary takings.

30. Pa. Coal, 260 U.S. at 415. 
the desire by a shorter cut than the constitutional way of paying for the change." 31

Put in other words, Pennsylvania Coal establishes that whether an enactment constitutes a taking depends in part on the values property owners enjoyed before the enactment. ${ }^{32}$

To modern "Scientific Policymakers," 33 who view property as a bundle of rights, the notion that the Takings Clause protects against legislative change might appear self-evident. But, as Robert Brauneis has demonstrated, until Pennsylvania Coal the Court often evaluated constitutional property claims not by measuring the effect of a legislative enactment on preexisting values, but rather by measuring the effect against an idealized conception of property rights divorced from preexisting positive law. If a legislative enactment aimed "at protecting the public side of an ideal boundary between owner and community," the enactment did not violate constitutionally protected property rights. ${ }^{34}$ Holmes's opinion in Pennsylvania Coal sounded the death knell for this view-a view that Holmes himself had long rejected. ${ }^{35}$

\section{Pennsylvania Coal and the Increased Importance of State Law}

Both Pennsylvania Coal's importance as the genesis of regulatory takings jurisprudence ${ }^{36}$ and its recognition that the Takings Clause protects against legal change ${ }^{37}$ have been well catalogued in the literature. By contrast, scholars have devoted little attention to Pennsylvania Coal's transformation of the significance of state law in takings cases. This transformation, however, has been critical in shaping current takings doctrine.

Before Pennsylvania Coal, preexisting state law played little role in assessing the constitutionality of legislatively enacted restrictions on property rights. Until enactment of the Fourteenth Amendment, the only

31. Id. at 416. A sentence earlier, Holmes questioned the propriety of "shifting" damages from one person to his neighbors. Id.

32. See Brauneis, supra note 21, at 621-24.

33. The term was coined in Bruce A. ACKerman, Private Property and THE CONSTITUTION 10 (1977), as a contrast to the "Ordinary Observer," who views private property as a unitary thing.

34. Brauneis, supra note 21 , at $631,628-31$.

35. See Treanor, supra note 21 , at $798-800$ (discussing Holmes's views as a lawyer and as a justice of the Massachusetts Supreme Judicial Court).

36. See, e.g., ACKERMAN, supra note 33, at 156 (describing Pennsylvania Coal as "the most important and most mysterious writing in takings law"); Richard A. Epstein, Takings: Descent and Resurrection, 1987 SUP. CT. REV. 1, 12 (describing it as "the single most important decision in the takings literature"); Treanor, supra note 21, at 798 (describing it as "the central case in modern takings law").

37. See, e.g., Brauneis, supra note 21 , at $628-33$. 
protection the Federal Constitution provided against state interference with property rights was the prohibition against impairing the obligation of contracts. ${ }^{38}$ The Court construed the Fifth Amendment's Takings Clause as a limitation only on the power of the federal government, not on the power of the states. ${ }^{39}$ In addition, until Congress enacted the Tucker Act in 1887, ${ }^{40}$ Congress retained sole responsibility for ascertaining and paying just compensation; takings claims against the federal government were thus nonjusticiable. ${ }^{41}$ Moreover, when the Court did discuss the scope of the Takings Clause, its focus was on appropriation of physical property, which the Court could ascertain without reference to state law. ${ }^{42}$

Even after property owners began to invoke the Fourteenth Amendment's Due Process Clause to challenge state legislation, the Court did not treat background state law as a significant aspect of the constitutional inquiry. As already noted, ${ }^{43}$ the Court employed a categorical distinction between exercises of the police power and exercises of the eminent domain power; regulations of property, however onerous, were enacted pursuant to the police power and required no compensation. By contrast, when a state engaged in direct physical appropriation, all states agreed that compensation was due. Hence, whenever a property owner challenged a regulation, it was unnecessary for the court to ascertain the content of background state law to determine whether compensation was due. ${ }^{44}$

38. U.S. CONST. art. I, $\S 10$ ("No State shall ... pass any ... Law impairing the Obligation of Contracts ....").

39. Barron v. Mayor of Balt., 32 U.S. (7 Pet.) 243, 250-51 (1833).

40. Tucker Act, ch. $359, \S 1,24$ Stat. 505, 505 (1887) (current version at 28 U.S.C. $\S \S 1346$, $1491(2000))$.

41. See Floyd D. Shimomura, The History of Claims Against the United States: The Evolution from a Legislative Toward a Judicial Model of Payment, 45 LA. L. REV. 625, 663-64 (1985); Treanor, supra note 21, at 794 n.69; $c f$. Langford v. United States, 101 U.S. 341, 343 (1879) ("It is to be regretted that Congress has made no provision by any general law for ascertaining and paying ... just compensation.").

In addition, William Stoebuck has demonstrated that until the Civil War, Congress looked to the states to condemn land needed by the federal government. William B. Stoebuck, $A$ General Theory of Eminent Domain, 47 WASH. L. REV. 553, 559 n.18 (1972).

42. In the Legal Tender Cases, 79 U.S. (12 Wall.) 457 (1870), the Court, upholding against a takings challenge a federal statute making all debts payable in United States currency rather than gold, wrote that the Takings Clause "has always been understood as referring only to a direct appropriation, and not to consequential injuries resulting from the exercise of lawful power." Id. at 551. Moreover, the focus on physical invasion was consistent with nineteenth-century practice in the state courts. See Treanor, supra note 21, at 792-94.

43. See supra text accompanying notes $21-29$.

44. The only contestable issue was whether the state's action constituted a physical appropriation, or only an indirect and noncompensable interference with the landowner. See, e.g., Gibson v. United States, 166 U.S. 269 (1897) (involving construction of a dike that obstructed the landowner's water access from his landing). These cases often arose in diversity cases where the Court was considering questions of common law, not interpreting the Federal Constitution. See, e.g., Transp. Co. v. Chicago, 99 U.S. 635 (1879) (involving temporary interference with boat 
Moreover, even if the Court had chosen to evaluate state regulatory enactments against background property law principles, nineteenth-century jurisprudential principles would not have required a close examination of state property law. The prevailing notion-developed most famously in Swift $v$. Tyson-was that the common law represented a single coherent body of principles resting upon "general reasoning and legal analogies." 45 Because property law was largely a common law discipline, close examination of state property law would have been unnecessary for the resolution of takings cases even if the Court had focused on how much the challenged enactment had altered preexisting property rights. ${ }^{46}$

On each of these questions, however, Justice Holmes's opinion in Pennsylvania Coal represented a significant departure from the previously dominant approach. First, Holmes rejected the categorical approach to property rights. Second, his embrace of a historical approach to the Takings Clause, focusing in part on diminution of value, required measuring the Kohler Act against prior law-and in particular, prior Pennsylvania law. Third, Holmes, as a consummate positivist, was an early critic of Swift $v$. Tyson and its jurisprudential underpinnings. ${ }^{47}$ Common law was the law of

access during construction of public improvements); Pumpelly v. Green Bay Co., 80 U.S. (13 Wall.) 166 (1871) (involving construction of a dam and consequent flooding).

45. 41 U.S. (16 Pet.) 1, 19 (1842) (Story, J.).

46. Cf. Frank I. Michelman, Property, Federalism, and Jurisprudence: A Comment on Lucas and Judicial Conservatism, 35 WM. \& MARY L. REV. 301, 307 (1993) (noting that property had a "strong naturalistic force" during the Gilded Age and the Lochner era).

47. Holmes criticized Swift v. Tyson most directly in his dissent in Black \& White Taxicab \& Transfer Co. v. Brown \& Yellow Taxicab \& Transfer Co., 276 U.S. 518 (1928):

If there were . . a transcendental body of law outside of any particular State but obligatory within it unless and until changed by statute, the Courts of the United States might be right in using their independent judgment as to what it was. But there is no such body of law. The fallacy and illusion that I think exist consist in supposing that there is this outside thing to be found. Law is a word used with different meanings, but law in the sense in which courts speak of it today does not exist without some definite authority behind it. The common law so far as it is enforced in a State, whether called common law or not, is not the common law generally but the law of that State existing by the authority of that State without regard to what it may have been in England or anywhere else.

Id. at 533-34 (Holmes, J., dissenting). But in an earlier dissent, Holmes had argued that state common law should bind the federal courts in cases involving real property:

It is said that we must exercise our independent judgment-but as to what? Surely as to the law of the States. Whence does that law issue? Certainly not from us. But it does issue and has been recognized by this court as issuing from the state courts as well as from the state legislatures. When we know what the source of the law has said that it shall be, our authority is at an end. The law of a State does not become something outside of the state court and independent of it by being called the common law. Whatever it is called it is the law as declared by the state judges and nothing else.

Kuhn v. Fairmont Coal Co., 215 U.S. 349, 372 (1910) (Holmes, J., dissenting). For a more modern discussion on the relationship between takings law and the "ghost" of Swift v. Tyson, see Michelman, supra note 46 , at 319-20. 
a particular state, and the impact of a state statute on property rights had to focus on the common law property rights of that state. ${ }^{48}$

Holmes's focus on state law played a significant role in Pennsylvania Coal itself. The Court's opinion emphasized that the Kohler Act "purports to abolish what is recognized in Pennsylvania as an estate in land-a very valuable estate-and what is declared by the Court below to be a contract hitherto binding the plaintiffs." 49

Thus, Holmes emphasized the effect of the Kohler Act in Pennsylvania, which had recognized separate estates in mining land, including a right to support of the surface - a right that could be transferred separately from the minerals or the surface and a right that the coal company had explicitly excepted when it executed the deed to the purchaser of the surface. ${ }^{50} \mathrm{Had}$ Pennsylvania not recognized a support estate that was alienable separately from the right to the surface, one might infer that the Court would have reached a different result. Moreover, even as to the "contract" claim, Holmes carefully noted that the statute abolished not a contract, but "what is declared by the Court below to be a contract." 51 The view of the Pennsylvania Supreme Court-not that of Holmes or his colleagues-was critical in defining the rights taken by the statute.

Thus, Pennsylvania Coal's legacy to the law of takings includes three innovations, not two. In addition to recognizing that regulations could infringe on constitutional protections of property and that those constitutional protections were protections against change, Pennsylvania Coal recognized that preexisting state law was critical in evaluating the constitutionality of regulatory enactments.

48. Holmes's most famous statement about the state authority that stands behind the common law is found in his dissenting opinion in Southern Pacific Co. v. Jensen, 244 U.S. 205 (1917): "The common law is not a brooding omnipresence in the sky but the articulate voice of some sovereign or quasi-sovereign that can be identified ...." Id at 222 (Holmes, J., dissenting).

49. Pa. Coal Co. v. Mahon, 260 U.S. 393, 414 (1922).

50. The coal company's brief emphasized that the "[t]hird estate"-- the support right - "has been recognized as so distinct from the ownership of the surface or of the minerals that it may be transferred to and held or conveyed by one who was neither the owner of the surface nor of the coal." Id. at 396.

One of the cases cited by the coal company was Charnetski v. Miner's Milis Coal Mining Co., 113 A. 683 ( $\mathrm{Pa} .1921$ ), in which the Pennsylvania Supreme Court wrote,

The principles here involved are covered by the cases of Graff Furnace Co. v.

Scranton Coal Co., $244 \mathrm{~Pa}$. 592, and Penman v. Jones, $256 \mathrm{~Pa}$. 416, both of which recognize that three estates may exist in land-the surface, the coal, and the right of support, and that each of these may be vested in different persons at the same time.

Id. at 684 (citations omitted); see also Young v. Thompson, 116 A. 297 (Pa. 1922).

51. Pa. Coal, 260 U.S. at 414 (emphasis added). 


\section{Regulatory Takings, State Law, and Takings Scholarship}

Takings scholarship has not completely ignored the state law foundation of takings doctrine. Frank Michelman, in particular, has recognized the importance of state law in shaping the Supreme Court's response to takings claims:

If a taking of property can occur only when a government in some way perpetrates a departure from the then-existing body of property law, then in order to tell whether a given state action takes property you have to know what the State's property law as a matter of fact is - what that law as a matter of fact says-at the moment when the action complained of takes place. ${ }^{52}$

Michelman has also observed that "questions about the content and meaning of state law normally are perceived as falling within the special domains of state courts" $" 53$ and has suggested that federalism principles might dictate Supreme Court "deference to state judiciaries in taking cases." 54 But Michelman's discussion of federalism concerns remains the exception rather than the rule in takings scholarship. As scholars, including Michelman himself, have developed sophisticated normative models to determine when landowners should be compensated, they have focused largely on identifying the instances in which compensation should be paid, not on identifying the appropriate decisionmaker. Michelman's 1967 $\operatorname{article~}^{55}$ - the starting point for most modern takings scholarship ${ }^{56}$-was designed to develop the "ethical foundations" of takings law, not to translate those rules into legal doctrine. ${ }^{57}$ Richard Epstein's much-cited book did focus on judicial doctrine, ${ }^{58}$ but Epstein's natural law orientation

52. Michelman, supra note 46 , at 310 .

53. Id. at 310-11.

54. Id. at 311 .

55. Frank I. Michelman, Property, Utility, and Fairness: Comments on the Ethical Foundations of "Just Compensation" Law, 80 HARV. L. REV. 1165 (1967).

56. Indeed, surveys of citation reveal that Michelman's article is one of the most cited law review articles of all time-on any subject. Fred R. Shapiro, The Most-Cited Law Review Articles, 73 CAL. L. REV. 1540, 1549 tbl.1 (1985) (listing Michelman's article as eighth most cited); Fred R. Shapiro, The Most-Cited Law Review Articles Revisited, 71 CHI.-KENT L. REV. 751, 766 tbl.1 (1996) (twelfth most cited).

57. In a more recent article, Michelman has described the appropriate judicial role as "elucidation (with specific reference to property) of a complex political ideal, that of constitutional democracy." Frank Michelman, The Common Law Baseline and Restitution for the Lost Commons: A Reply to Professor Epstein, 64 U. CHI. L. REV. 57, 67 (1997). In particular, he argues that "if, in the general context of American constitutionalism, it is unfair for politics to impose on property in the challenged way without compensation, then property has been taken, and vice-versa." $I d$.

58. Epstein did not contend that his analysis described existing takings doctrine. Indeed, he explicitly called for increased judicial intervention to protect property owners. RICHARD A. 
led him to recognize a single "correct" common law; state departures from that norm were merely errors to be corrected. ${ }^{59}$ Federalism considerations, therefore, have no place in Epstein's analysis. ${ }^{60}$ Several incisive economic analyses of the takings problem have focused little attention on the appropriate role for the Supreme Court in formulating takings doctrine. ${ }^{61}$ And among the eminent process theorists who have focused on allocation of takings responsibility between courts and legislatures, ${ }^{62}$ only economist

EPSTEIN, TAKINGS: PRIVATE PROPERTY AND THE POWER OF EMINENT DOMAIN 30-31 (1985) ("I shall advocate a level of judicial intervention far greater than we now have, and indeed far greater than we ever have had.").

59. For instance, building on his own common law scholarship, Epstein's Takings rejects negligence-based tort liability and explicates nuisance liability as if the genius of his own theory of nuisance liability were universally accepted. See id. at 40-41, 116-21. For more extensive development of Epstein's common law theories in these areas, see Richard A. Epstein, Nuisance Law: Corrective Justice and lts Utilitarian Constraints, 8 J. LEGAL STUD. 49 (1979); and Richard A. Epstein, $A$ Theory of Strict Liability, 2 J. LEGAL STUD. 151 (1973).

60. Epstein's response to federalism concerns is twofold. First, as a practical matter, he contends that the differences among the states, at least with respect to common law, are not significant. With respect to state nuisance law, for instance, he writes,

I confess that I do not think that this problem is as large as it is sometimes made out to be if only because the level of agreement across states is far greater than is sometimes supposed, in part because of the unifying forces created by the Restatements and the standard treatises on the subject.

Richard A. Epstein, Takings, Exclusivity and Speech: The Legacy of PruneYard v Robins, 64 U. CHI. L. REV. 21, 41 (1997); see also id. at 24 (asserting that the " "brooding omnipresence' of common law rules ... is manifestly, but imperfectly, connected with the law in any given state").

Second, Epstein, relying on Locke, argues that common law property rules precede the state, whose function is "to stabilize and protect the rights created exclusively by private individuals in the course of their ordinary actions." Id. at 26. On this theory, property rights derive from natural law, and when a state departs significantly from the norm dictated by natural law, the state acts without justification.

Epstein's arguments are-as he would probably concede-inconsistent with both the positivism and the federalism inherent in Justice Holmes's opinion in Pennsylvania Coal.

61. In particular, Lawrence Blume and Daniel Rubinfeld have demonstrated that compensation for losses imposed by government activity can reduce inefficiencies that result from failure in the market for private insurance. Lawrence Blume \& Daniel L. Rubinfeld, Compensation for Takings: An Economic Analysis, 72 CAL. L. REV. 569 (1984). Blume and Rubinfeld do not, however, discuss mechanisms for assuring that compensation is paid in those instances where their model would require compensation. Indeed, they concede that they have not "discussed in any detail whether a legislatively constituted compensating body is appropriate." Id. at 624 .

Michael Heller and James Krier have argued that the twin concerns of utility and fairness are more likely to be realized if the legal system uncouples two aspects of the compensation decision: payment by the government and receipt by the affected landowner. Michael A. Heller \& James E. Krier, Deterrence and Distribution in the Law of Takings, 112 HARV. L. REV. 997, 997-1005 (1999). They establish that in many circumstances no individual landowner need receive compensation in order to achieve optimal deterrence. Id. at 1003-04, 1006. For them, however, "[t]he question of appropriate limitations on the scope of judicial review is not our problem." Id. at 1025 .

62. For these scholars, land use issues are fundamentally political in nature and should be resolved by the political branches unless some systemic failure in the legislative process requires judicial intervention. See Daniel A. Farber, Economic Analysis and Just Compensation, 12 INT'L REV. L. \& ECON. 125, 130 (1992) (arguing that landowners generally have advantages in obtaining compensation through political processes); Saul Levmore, Just Compensation and Just 
William Fischel has explicitly considered the allocation of responsibility between state courts and the Supreme Court ${ }^{63}$-albeit with the unsystematic conclusion that the Supreme Court's role should be to "supervise state courts whose political inclinations have been to read the regulatory side of the Just Compensation Clause out of the Constitution." 64

In other words, takings scholarship has fully absorbed two of the three innovations Pennsylvania Coal brought to takings doctrine. Regulation as taking-Justice Holmes's first innovation-serves as the starting point for most takings scholarship. With the exception of Epstein, takings scholars generally accept Holmes's second innovation-that the Takings Clause protects against change. Only Michelman and Fischel have attempted to integrate Pennsylvania Coal's third insight-that takings doctrine is heavily dependent on state law-into their analyses of takings

Politics, 22 CONN. L. REv. 285 (1990); Saul Levmore, Takings, Torts, and Special Interests, 77 VA. L. REV. 1333, 1345, 1357-59 (1991) (noting that the potential for legislative failure exists in two classes of cases - those where a small identifiable group of persons would benefit from the proposed government action and those where an individual singled out for harm is not part of an easily organized political coalition); Glynn S. Lunney, Jr., A Critical Reexamination of the Takings Jurisprudence, 90 MICH. L. REV. 1892, 1943, 1950 (1992) (finding no reason to expect that courts will be better than legislatures at resolving compensation issues, except when proposed government action would benefit a dispersed group at the expense of a concentrated minority); Treanor, supra note 21 , at 869 (writing that the "political process generally protects landowners from the risk of uncompensated confiscation," and that compensation is warranted only in cases involving discrete and insular minorities).

63. Much of Fischel's earlier work is collected in his book, WILliam A. FISCHEL, REGULATORY TAKINGS: LAW, ECONOMICS, AND POLITICS (1995). Among those earlier articles are William A. Fischel, Exploring the Kozinski Paradox: Why Is More Efficient Regulation a Taking of Property?, 67 CHI.-KENT L. REV. 865 (1991), and William A. Fischel \& Perry Shapiro, Takings, Insurance, and Michelman: Comments on Economic Interpretations of "Just Compensation" Law, 17 J. LEGAL STUD. 269 (1988).

Fischel distinguished regulation enacted at the state or federal level, where political processes should generally provide adequate protection against government abuse, from regulations enacted at the local level, where political process defects require more searching judicial review. He recommended that "courts largely avert their eyes from the regulatory excesses of Congress and, for the most part, of state legislatures." FISCHEL, supra, at 140. He did so because "[t]hose affected by the laws have access to the political process that makes the rules, and threats to move out or not move in are taken seriously." Id. at 133. Fischel attempted to provide empirical support for his claim by cataloging situations in which nonjudicial constraints prevented Congress or state legislatures from enacting takings-like legislation without providing adequate compensation to aggrieved parties. Id. at 289-303.

By contrast, Fischel concluded that the absence of both "exit" and "voice" put owners of immobile property at the mercy of local governments, requiring the protection of judicial review. $I d$. at 139,324 . Fischel did not explain, however, why landowners victimized by local regulation could not seek redress at the state or federal level where, by hypothesis, they are adequately represented. See Treanor, supra note 21, at 868-69; James E. Krier, Takings from Freund to Fischel, 84 GEO. L.J. 1895, 1910-11 (1996) (book review); Carol M. Rose, Takings, Federalism, Norms, 105 YALE L.J. 1121, 1140-41 (1996) (book review).

Moreover, as Carol Rose has noted, landowners face problems of exit at every level of government, and there is little reason to believe their voice will be more effective at state and federal levels than at the local level. Rose, supra, at 1134-38.

64. FisCHEL, supra note 63, at 6. Fischel had in mind the California Supreme Court, the decisions of which he discusses at length. Id. at 52-59. 
jurisprudence. Michelman, however, stopped short of developing a comprehensive descriptive or normative analysis of the role of the Supreme Court in takings cases. And Fischel's analysis, however cogent on policy issues, is understandably thin on issues of constitutional doctrine.

\section{TAKINGS IN A FEDERAL SYSTEM: STATE LAW AND THE SUPREME COURT OF THE UNITED STATES}

Part I demonstrated that takings doctrine is dependent on the content of background state law-a dependence underappreciated in takings commentary. What implications does that dependence have for Supreme Court review of takings claims? Part II establishes that dependence on state law complicates Supreme Court takings adjudication while reducing the value of that review in two respects: First, active Supreme Court review of takings claims would provide little guidance to courts and other decisionmakers; second, active review would not significantly advance uniform application of constitutional law. Taken together, these factors counsel limited Supreme Court involvement in takings cases.

\section{A. State Law and the Supreme Court in the Enforcement of Federal Constitutional Rights}

The Federal Constitution protects against a variety of government intrusions on individual rights. Although particular provisions of state law may precipitate disputes over federal constitutional rights, state law generally plays no role in determining the level of federal constitutional protection. Instead, an adjudicating court measures the challenged law or government action against the benchmark established by the federal constitutional guaranty. ${ }^{65}$ Consider, for example, the First Amendment's free speech guaranty. ${ }^{66}$ Whether a state's cross-burning statute violates the Federal Constitution does not depend on the content of other state laws; instead, the constitutional question is whether the statute falls within federally defined classes of speech whose "value as a step to truth" is "outweighed by the social interest in order and morality." ${ }^{\text {"67 }}$ A similar

65. As Akhil Amar has put it, "[T]he federal Constitution stands as a secure political safety net-a floor below which state law may not fall." Akhil Reed Amar, Philadelphia Revisited: Amending the Constitution Outside Article V, 55 U. CHI. L. REV. 1043, 1100 (1988).

66. See, e.g., Virginia v. Black, 538 U.S. 343 (2003) (invalidating Virginia's cross-burning statute as inconsistent with the First Amendment's free speech guaranty).

67. Id. at 358-59. Incorporation of "contemporary community standards" into the First Amendment's obscenity jurisprudence does not alter the analysis. Once the Court decided that identifying obscenity is in some measure a question of fact for juries, the Court recognized that "[t]o require a State to structure obscenity proceedings around evidence of a national "community 
constitutional rubric governs the Fourth Amendment's right to be free of unreasonable searches and seizures ${ }^{68}$ and almost every other constitutional protection of individual rights.

At first glance, Equal Protection Clause analysis appears to depend on background state law: Whether the state unconstitutionally discriminates against one person or class depends to some extent on how the state treats other persons or classes. But in fact, as the Supreme Court has developed its equal protection jurisprudence, almost all the analytical work focuses on classification of the parties and the rights involved, and background state law is irrelevant to that classification system. ${ }^{69}$ Thus, most equal protection claims are subject to "rational basis" review, which virtually any state enactment, however discriminatory, will survive. ${ }^{70}$ By contrast, if the Court concludes that the discrimination involves a suspect class ${ }^{71}$ or a

standard' would be an exercise in futility." Miller v. California, 413 U.S. 15, 30 (1973). The problem was that the ordinary juror might be familiar only with standards in her own community, not standards applicable in other areas of the nation. See id. at 32-33. At the same time, community standards become relevant only in circumstances where those standards do not conflict with substantive First Amendment standards. As then-Justice Rehnquist put it in Jenkins v. Georgia, 418 U.S. 153 (1974), Miller "was certainly intended to fix substantive constitutional limitations, deriving from the First Amendment, on the type of material subject to such a [community standards] determination." Id. at 160-61.

68. See, e.g., Atwater v. City of Lago Vista, 532 U.S. 318 (2001) (upholding a warrantless search for a minor criminal offense).

69. Larry Kramer has described the Supreme Court's development of "tiers of scrutiny" as recognition of the relative capacities of courts and legislatures:

The tiers of scrutiny in equal protection law are grounded in judicial recognition that courts are institutionally either worse or no better than legislators at making certain kinds of decisions.

... It is the very nature of law to draw classifications and create categories. Hence, the Equal Protection Clause potentially subjected every law to judicial scrutiny, and read for all it was worth, would have authorized judges to second-guess every legislative and executive decision. The tiers of scrutiny ... were a response: an effort to cordon off a domain in which judicial reexamination of legislation made sense given the relative institutional capacities of courts and legislatures.... Heightened scrutiny reflects our sense that courts are capable of evaluating legislative justifications against something like the social and historical background of race or gender relations, particularly after the judicial task has been simplified by an evidentiary presumption that confines the inquiry to whether there are compelling reasons to discriminate. In other areas, no such presumption is warranted, and the question whether two things can or should be treated differently calls for a kind of judgment that is preeminently legislative in nature. These decisions are left to be made outside the courthouse, subject to judicial scrutiny only to ensure that government officials have an explanation and that it is not utter nonsense.

Larry D. Kramer, The Supreme Court, 2000 Term-Foreword: We the Court, 115 HARV. L. REV. 4, 146-47 (2001).

70. See, e.g., Fitzgerald v. Racing Ass'n of Cent. Iowa, 539 U.S. 103 (2003) (upholding an Iowa tax statute providing for a lower tax rate for riverboat slot machines than for racetrack slot machines).

71. Although African Americans were the original suspect class, the Court has extended the same treatment to other disadvantaged groups. See Plyler v. Doe, 457 U.S. 202 (1982) (classifying children of illegal aliens as a disadvantaged group). Moreover, the Court has more 
fundamental right ${ }^{72}$-classifications that depend not at all on state law-the Court applies strict scrutiny to the state enactment. In that case, too, the result is almost preordained. ${ }^{73}$ As Gerald Gunther once put it, strict scrutiny is "strict' in theory and fatal in fact." Even when the Court has determined that an "intermediate" level of scrutiny should apply-largely in cases of gender discrimination - state law plays a relatively minor role in the analysis: In light of the strong presumption that gender discrimination is invalid, a state seeking to defend gender discrimination faces a heavy burden. ${ }^{75}$ Thus, in practice, equal protection analysis, like analysis of free speech or search and seizure issues, focuses on the challenged enactment, not on the content of background state law.

State legislators and other state officials nevertheless play an important role in enforcing constitutional rights and shaping constitutional values. Many potential federal constitutional conflicts do not arise because legislators or other state officials take constitutional commands into account in performing their governmental functions. ${ }^{76}$ When litigation does

recently concluded that all classifications based on race, even those designed to favor African Americans, should be treated as suspect. Adarand Constructors v. Pena, 515 U.S. 200 (1995).

72. The first fundamental right to trigger strict scrutiny was the right to avoid forced sterilization. See Skinner v. Oklahoma ex rel. Williamson, 316 U.S. 535 (1942); see also Shapiro v. Thompson, 394 U.S. 618 (1969) (extending similar treatment to the right to travel), overruled in part by Edelman v. Jordan, 415 U.S. 651, 671 (1974); Harper v. Va. State Bd. of Elections, 383 U.S. 663 (1966) (extending similar treatment to the right to vote).

73. In rare cases, the Court has found a compelling state interest that justifies discrimination based on a suspect classification. Grutter v. Bollinger, 539 U.S. 306 (2003), in which the Court concluded that diversity was a compelling justification for race-based discrimination by the University of Michigan Law School, is a notable example. In Grutter, however, the discrimination benefited members of a disadvantaged group.

74. Gerald Gunther, The Supreme Court, 1971 Term-Foreword: In Search of Evolving Doctrine on a Changing Court: A Model for a Newer Equal Protection, 86 HARV. L. REV. 1, 8 (1972). But see Adarand, 515 U.S. at 237 (seeking to dispel the notion that strict scrutiny is strict in theory but fatal in fact).

75. See United States v. Virginia, 518 U.S. 515, 532-33 (1996) (invalidating the exclusion of women from the Virginia Military Institute).

Mary Anne Case has described the Court's treatment of the constitutionality of sex discrimination in terms independent of background state law principles: "To determine whether there is unconstitutional sex discrimination, one need generally ask only two questions: 1) Is the rule or practice at issue sex-respecting, that is to say, does it distinguish on its face between males and females? and 2) Does the sex-respecting rule rely on a stereotype?" Mary Anne Case, "The Very Stereotype the Law Condemns": Constitutional Sex Discrimination Law as a Quest for Perfect Proxies, 85 CORNELl L. REV. 1447, 1449 (2000) (footnote omitted).

76. What account legislative and executive officials should take of constitutional norms has been the subject of practical and scholarly debate. On a practical level, President Franklin Roosevelt, in urging passage of New Deal legislation of questionable constitutionality, suggested that Congress should focus entirely on policy questions, leaving constitutional questions for the courts. Letter from President Franklin D. Roosevelt to Congressman Samuel B. Hill (July 6, 1935), in 4 THE PUBLIC PAPERS AND ADDRESSES OF FRANKLIN D. ROOSEVELT 297-98 (Samuel I. Rosenman ed., 1938). Ronald Dworkin has provided a scholarly foundation for Roosevelt's position, noting that legislatures have institutional advantages in deciding matters of policy, while courts have advantages in deciding matters of principle. RONALD DWORKIN, LAW'S EMPIRE 219$24,242-44,310-12(1986)$. 
arise, state courts often construe state statutes and constitutions to avoid federal constitutional conflicts. ${ }^{77}$ In other cases, state courts (and federal district and circuit courts) enforce federal constitutional commands. ${ }^{78}$ Indeed, the U.S. Supreme Court-the ultimate arbiter of federal constitutional disputes-resolves only a tiny percentage of federal constitutional claims. $^{79}$

The Supreme Court's role in constitutional litigation, however limited, remains critical. The Court's opinions provide guidance to state and federal courts-and state and federal officials-wrestling with similar

On the other hand, Lawrence Sager stimulated early support for independent constitutional interpretation by arguing that the Supreme Court's decision not to enforce a right might rest on institutional rather than analytical considerations, and that the Court might decline enforcement precisely because it concludes that enforcement is better entrusted to other branches. Lawrence Gene Sager, Fair Measure: The Legal Status of Underenforced Constitutional Norms, 91 HARV. L. REV. 1212, 1217-28 (1978). Academic support for constitutional interpretation by the political branches has become part of the mainstream. See, e.g., Neal Devins \& Louis Fisher, Judicial Exclusivity and Political Instability, 84 VA. L. REV. 83, 101 (1998) ("JJ]udicial exclusivity is likely to marginalize the Court and, with it, the Constitution. Democratic institutions will only take the Constitution seriously if they have some sense of stake in it."); Neal Kumar Katyal, Legislative Constitutional Interpretation, 50 DUKE L.J. 1335, 1364 (2001) ("Some constitutional questions require a high degree of understanding about popular mores .... Such questions are better suited to legislative determinations than determination by the insulated Court.").

Recent debate has shifted to more extreme positions. For instance, Michael Paulsen has argued that other branches of government should engage in independent interpretation even when that interpretation conflicts with established judicial interpretation. E.g., Michael Stokes Paulsen, The Most Dangerous Branch: Executive Power To Say What the Law Is, 83 GEO. L.J. 217, 34345 (1994). Mark Tushnet has argued that courts should abandon much judicial review of legislation to foster greater legislative deliberation on constitutional questions. MARK TUSHNET, TAKING THE CONSTITUTION AWAY FROM THE COURTS 57-63 (1999). Larry Alexander and Frederick Schauer have explicitly rejected these arguments, contending that judicial supremacy in constitutional adjudication serves important values. Larry Alexander \& Frederick Schauer, On Extrajudicial Constitutional Interpretation, 110 HARV. L. REV. 1359, 1372-82 (1997) (discussing settlement and consistency values advanced by judicial supremacy).

77. Thus, if a state court construes a statute to avoid conflict with a federal constitutional provision or construes the state constitution to invalidate the state statute, no federal constitutional question is raised, and there is no need or opportunity for review by the U.S. Supreme Court, because the state court's decision rests on an adequate state ground. $C f$. Herb v. Pitcairn, 324 U.S. $117,125-26$ (1945) ("Our only power over state judgments is to correct them to the extent that they incorrectly adjudge federal rights. And our power is to correct wrong judgments, not to revise opinions."); Sandra Day O'Connor, Our Judicial Federalism, 35 CASE W. RES. L. REV. 1, 5 (1984-1985) ("The point I wish to stress is that, especially in the constitutional context, state courts have substantial power to grant or withhold jurisdiction to the Supreme Court by the choice and articulation of the grounds for the state court decisions.").

78. See, e.g., Winter v. DC Comics, 69 P.3d 473 (Cal. 2003) (enforcing a First Amendment limitation on state right of publicity); Opinion of Justices to the House of Representatives, 702 N.E.2d 8 (Mass. 1998) (invalidating a reduced vehicle rental surcharge for state residents as inconsistent with the dormant Commerce Clause limitation).

79. In fiscal year 2003, for instance, the federal courts alone had 252,962 civil filings (constitutional and nonconstitutional), while in 2002, the Supreme Court had 8255 filings and heard argument in 84 cases, 79 of which were disposed of in 71 published opinions. SUPREME COURT OF THE UNITED STATES, 2003 YEAR-END REPORT ON THE FEDERAL JUDICIARY (2004), available at http://www.supremecourtus.gov/publicinfo/year-end/2003year-endreport.html. These statistics, of course, exclude filings in state court. 
constitutional questions. That guidance is particularly important when conflicts among state and federal courts would otherwise provide for unequal enforcement of federal constitutional law. ${ }^{80}$

\section{B. State Law and Takings Adjudication}

The Fifth Amendment provides that "private property" shall not be "taken for public use, without just compensation." If "private property" were defined federally_as the Supreme Court has been willing to define "speech" for First Amendment purposes, "search" for Fourth Amendment purposes, and "equal protection" for Fourteenth Amendment purposes-the Supreme Court could easily play a role in takings litigation akin to the role it plays in other constitutional adjudication. But within our federal system, definition of property rights has generally been left to the states. ${ }^{81}$ As a result, it appears that whether the government has taken property in violation of the Fifth Amendment must depend in considerable measure on state law; if state law did not create property in the first instance, then subsequent state action cannot take property. ${ }^{82}$ The Supreme Court's role is limited to defining the outer bounds of what might count as "property" for Takings Clause purposes. ${ }^{83}$ Within those bounds, the Supreme Courtfrom Justice Holmes in Pennsylvania Coal ${ }^{84}$ to Justice Scalia in Lucas $^{85}$ has explicitly acknowledged the primacy of state law in determining whether "property" has been taken. ${ }^{86}$

80. See, e.g., O'Connor, supra note 77 , at 5 (maintaining that one of the Supreme Court's most important functions is to create and preserve uniformity of interpretation).

81. As the Supreme Court explained in Board of Regents v. Roth, 408 U.S. 564 (1972), "Property interests, of course, are not created by the Constitution. Rather, they are created and their dimensions are defined by existing rules or understandings that stem from an independent source such as state law...." Id. at 577.

82. As Melvyn Durchslag has put it, "Property ... owes both its existence and its contours to positive law, local positive law. Property simply does not exist in the absence of state law." Melvyn R. Durchslag, Forgotten Federalism: The Takings Clause and Local Land Use Decisions, 59 MD. L. REV. 464, 494 (2000) (footnotes omitted).

83. See infra text accompanying notes 100-103.

84. Pa. Coal Co. v. Mahon, 260 U.S. 393, 414 (1922) ("[T] purports to abolish what is recognized in Pennsylvania as an estate in land ....").

85. Lucas v. S.C. Coastal Council, 505 U.S. 1003, 1029 (1992) (noting that to be valid, regulations that prohibit all economically beneficial use of land "must... do no more than duplicate the result that could have been achieved in the courts-aby adjacent landowners... under the State's law of private nuisance, or by the State under its complementary power to abate nuisances that affect the public generally, or otherwise").

86. See Keystone Bituminous Coal Ass'n v. DeBenedictis, 480 U.S. 470, 475-77 (1987) (discussing background Pennsylvania law); id. at 500-01 (discussing the impact of Pennsylvania's recognition of unique "support estate" on a takings claim); PruneYard Shopping Ctr. v. Robins, 447 U.S. 74, 84 (1980) ("Nor as a general proposition is the United States, as opposed to the several States, possessed of residual authority that enables it to define 'property' in the first instance."). 
Differences among the states in defining property rights are not merely hypothetical; they are real and can have substantial implications for takings doctrine. To take one example, state common law property regimes differ significantly in the rights they accord to waterfront landowners. Oregon, for instance, recognizes customary rights in the public to traverse the dry-sand area between ordinary high tide and the vegetation line. ${ }^{87}$ As a result, waterfront landowners may not take any steps to obstruct the dry-sand area. ${ }^{88}$ Other states purport to recognize customary rights but impose proof requirements so onerous that "custom" will rarely obstruct the plans of a waterfront owner. ${ }^{89}$ New Hampshire is among a group of other states that reject customary rights altogether. ${ }^{90}$ Suppose, now, that two coastal municipalities, one in Oregon and one in New Hampshire, enact identical ordinances prohibiting construction of any residence, or any accessory structure, within 100 feet of the mean high-water mark. It ought to be evident-especially against the background of Pennsylvania Coal-that an owner of property along the New Hampshire shoreline has a stronger constitutional claim than a similarly situated Oregon landowner. ${ }^{91}$

This dependence of constitutional rights on state law is not unique to Takings Clause litigation. Property's state law foundation has raised difficult issues with respect to the scope of the Due Process Clause, which prohibits deprivation of "property" without "due process of law." 92 And

87. State ex rel. Thornton v. Hay, 462 P.2d 671, 676-78 (Or. 1969). In explaining the doctrine, the court noted,

The record shows that the dry-sand area in question has been used, as of right, uniformly with similarly situated lands elsewhere, and that the public's use has never been questioned by an upland owner so long as the public remained on the dry sand and refrained from trespassing upon the lands above the vegetation line. Id. at 677 .

88. Id. at 673 .

89. See, e.g., State ex rel. Haman v. Fox, 594 P.2d 1093, 1101 (Idaho 1979) (holding that the doctrine of custom forms part of the law of Idaho but that the doctrine only applies when customary use has existed for time immemorial and that use since 1912 did not satisfy the doctrinal requirement).

90. See Opinion of the Justices (Public Use of Coastal Beaches), 649 A.2d 604, 608, 611 (N.H. 1994) (holding that waterfont landowners in New Hampshire enjoyed rights from the land to the high-water mark and that legislative efforts to create a recreational easement across the drysand area would require compensation to affected landowners); see also Purdie v. Attorney Gen., 732 A.2d 442 (N.H. 1999) (rejecting as unconstitutional a legislative effort to redefine the highwater mark).

91. Cf. Stevens v. City of Cannon Beach, 854 P.2d 449 (Or. 1993) (rejecting a waterfront landowner's constitutional challenge to the municipality's denial of permits to build a privacy sea wall).

92. U.S. CONST. amend. V; id. amend. XIV. In recent decades, the prohibition on deprivation of property without due process of law has largely been a mechanism to protect persons against arbitrary government action. Board of Regents v. Roth, 408 U.S. 564 (1972), established that procedural due process protections are available only when state acticns threaten interests that qualify as "liberty" or "property." Id. at 569. Roth did not, however, offer a federal constitutional definition of property. Id. at 577. For additional discussion of the difference in the meaning of 
because our federal system has generally committed to the states the power to develop bodies of contract law, constitutional claims that a state has passed a "Law impairing the Obligation of Contracts" $" 93$ have the potential to raise similar issues.

In each of these areas, one might argue that state law should be irrelevant in determining what constitutes "property" or "contract" for federal constitutional purposes. If the Federal Constitution imbues a word with federal constitutional significance, then the word should be defined in a way that reflects that significance. ${ }^{94}$ If the Takings, Due Process, and Contracts Clauses are designed to protect individuals against changes imposed by state officials, federal constitutional standards are necessary to determine what interests are entitled to protection against change. ${ }^{95}$ Moreover, any search of state law for definitions of "contract" or "property" will inevitably prove quixotic, because state law will (and should) define those terms differently for different purposes. Thus, what constitutes "property" for purposes of taxation may be very different from what constitutes "property" for various inheritance law purposes. 96

As powerful as these objections to a state law definition of constitutionally protected property might be, any effort to develop an exclusively federal definition is doomed to failure. The Framers themselves

property for the purpose of implementing different constitutional provisions, see Thomas $\mathrm{W}$. Merrill, The Landscape of Constitutional Property, 86 VA. L. REV. 885 (2000).

93. U.S. CONST. art. I, $\S 10, \mathrm{cl} .1$.

94. See, e.g., Williams v. North Carolina, 325 U.S. 226, $231 \mathrm{n} .7$ (1945) (noting that because "domicil"- a term ordinarily defined by state law - had become critical for constitutional law purposes, "the proper criteria for ascertaining domicil, should these be in dispute, become matters for federal determination").

95. Richard Epstein makes the point most forcefully: "When the Fifth Amendment states that private property cannot be taken for public use without just compensation, one can hardly suppose that a state is able to deflect the power of this constitutional command by defining property in ways that exclude some of its essential attributes." Epstein, supra note 60, at 25. Frank Michelman has also articulated, without explicitly endorsing, the critique of the positivist view that property for constitutional purposes must be defined by the states:

According to a so-called positivist view, a property holding's scope is always necessarily hostage to state lawmaking. "Property," in this view, consists of nothing but the law's confirmation of entitlements and prerogatives to possessors or other "owners." Property's content, therefore, can be nothing but the sum of whatever such confirmations a state's laws from time to time see fit to include... . Can such an accordion-like conception of property possibly serve as the baseline for constitutional "taking" determinations? If it did, then arguably there could be no such constitutionally cognizable event as a "regulatory taking"....

Michelman, supra note 57, at 57-58.

96. See, e.g., In re Cassidy's Estate, 118 A. 725 (Me. 1922) (holding that a contingent remainder does not constitute property for state inheritance tax purposes); Emmons v. Shaw, 50 N.E. 1033, 1035 (Mass. 1898) (holding that property subject to the power of appointment is the donor's property for inheritance tax purposes, but conceding that "for some purposes . . . the execution of the power by will constitutes the property assets of the donee's estate"). 
were familiar with a variety of state and local regulations of land use. ${ }^{97}$ Indeed, as a member of the Virginia House of Delegates, James Madison participated in a significant redefinition of common law property rights; he supported abolition of the entail and introduced legislation to abolish joint tenants' right of survivorship. ${ }^{98}$ Yet Article I of the Federal Constitution confers on Congress no general power to define or regulate property rights. And the Takings Clause itself provides no foundation for developing a peculiarly federal definition of property. The strong inference, supported by the Court's statements, ${ }^{99}$ is that the Federal Constitution is generally indifferent to the forms of property or contract recognized by the several states; the Constitution's concern is with change in those rights, not with their initial form or content.

Recognizing this problem, Thomas Merrill has suggested that the constitutional definition of property is, in fact, an amalgam of state and federal law. ${ }^{100}$ Federal law determines what categories of legally protected interests might qualify as constitutional property; whether interests that fall within those categories have actually been created remains a matter of state law. ${ }^{101}$ And the categories might well be different for different constitutional protections, each of which serves a different constitutional purpose. ${ }^{102}$ Merrill's formulation-any sensible formulation-leaves much room for state law. If the Takings Clause protects against change, the question must be "change from what?" and the "from what" question must be answered by reference to state law. State definitions will not always be controlling: If a state were to label the broad right to disseminate pornography a "property" right, the state's alteration or withdrawal of that right would be excluded from treatment as constitutional property because the right to disseminate pornography falls outside the (federally determined) categories of property rights. ${ }^{103}$ Hence, the Takings and Due

97. See John F. Hart, Land Use Law in the Early Republic and the Original Meaning of the Takings Clause, 94 Nw. U. L. REV. 1099, 1107-31 (2000).

98. Id. at 1130 .

99. See, e.g., Bd. of Regents v. Roth, 408 U.S. 564, 577 (1972) ("Property interests, of course, are not created by the Constitution.").

100. See Merrill, supra note 92, at 942-99.

101. Merrill calls his method a "patterning definition" approach. Id. at 893. Courts "seek to discover from the Constitution's traditions general criteria that serve to differentiate property rights from other types of interests." Id. at 952. Then, "state law is consulted not to discover the definition of property; it is reviewed to determine if interests have been created that correspond to the federal criteria for the identification of constitutional property." Id.

102. Id. at 955-69.

103. As a matter of constitutional interpretation, the case for excluding pornography dissemination from the category of constitutionally protected property is particularly strong because another, more specific constitutional provision-the First Amendment-provides protection against speech restrictions. Against that background, it would be peculiar to conclude that the general language of the Fifth Amendment was intended to constrain state regulation of pornography. The same analysis would counsel against locating within the Fifth Amendment's 
Process Clauses would have no concern with these changes, regardless of the state definition. Nevertheless, no plausible takings claim can be resolved without careful consideration of preexisting state law.

\section{Guidance, Uniformity, and the Limited Value of Supreme Court Review in Takings Litigation}

The dependence of takings claims on state law creates three difficulties for Supreme Court review. First, dependence on state law makes adjudication of takings claims more complex. Second, the state-specific nature (and sometimes municipality-specific nature) of takings claims reduces the guidance value of Supreme Court decisions. Third, property law's foundation in state law reduces the Supreme Court's ability to enforce uniform application of constitutional norms.

\section{Complexity}

First, consider the complications introduced by the state law foundation of takings law. Whenever the Supreme Court considers the constitutionality of state regulation, it must examine the regulation's scope: What does the regulation permit or prohibit? Takings challenges differ from other constitutional challenges to state regulation, however, because the Court must also examine the state law background: What did state law permit and prohibit before enactment of the challenged regulation? Often, that question cannot be answered by a quick check of state statutes. Instead, the reviewing court will have to master common law nuances to understand the background law and therefore the statute's effect. Lucas ${ }^{104}$ provides an example, both of the problem and of the Supreme Court's reluctance to tackle it. The Court held that the South Carolina Coastal Council's development ban worked a taking of Lucas's land-unless South Carolina's background nuisance law would have prohibited development of

property provisions any protection of the right to bear arms (Second Amendment) or the right to be free of particular criminal punishments (Eighth Amendment), however a state decided to characterize those rights.

Even when a state-created right does not fall within the subject matter of another federal constitutional provision, the state's characterization of that right as "property" would not be conclusive for takings purposes if the right does not fall within categories-derived from the Constitution's traditions-that, in Merrill's words, "serve to differentiate property rights from other types of interests." Id. at 952 . Among those categories are interests regarded as property as a matter of private common law: "real property interests, personal property interests, intellectual property interests, and securities." Id. at 979-80. By contrast, a right to consume alcohol, or a right to ride a motorcycle without a helmet, might not constitute a property right for takings purposes, however those rights might be characterized as a matter of state law.

104. Lucas v. S.C. Coastal Council, 505 U.S. 1003 (1992). 
the land. ${ }^{105}$ But rather than attempting to unpack the nuisance law, the Court remanded to the South Carolina Supreme Court for a determination of that issue. ${ }^{106}$

By focusing primarily on nuisance law, Lucas understated the complexities involved in ascertaining whether background state law would have prohibited development of the Lucas parcel. Nuisance represents only one of the potential common law constraints on the development of waterfront land. Some states, for instance, recognize public prescriptive easements to cross dry-sand beaches, which limit landowners' development rights. ${ }^{107}$ In other states, the public trust doctrine may prevent development of beachfront land whether or not members of the public have previously and continuously used the beaches. ${ }^{108}$ Determining background property rights, then, may require examination of a variety of common law doctrines.

Moreover, because the Coastal Council had made it clear that no development would be permitted on the Lucas parcel, the Supreme Court faced complexity only in assessing background state law. In many other cases, however, the municipality's actions leave unclear what rights the landowner retains as a result of regulatory activity. As a result, courts face difficulties in assessing a landowner's rights both before and after the challenged state action. City of Monterey v. Del Monte Dunes at Monterey, $L t d .^{109}$ presents a not-atypical case. The municipality had in place a zoning ordinance together with a planning process that vested discretion in a city planning commission to evaluate particular development plans to assure adequate access, minimize environmental impact, and accomplish other planning objectives. The planning commission subsequently rejected a series of plans offered by the developer, leading the developer to believe that the commission would never approve any development plan. ${ }^{110}$ In order to evaluate a developer's claim that a planning commission's action worked a taking, a reviewing court must ascertain the rights the developer enjoyed both before and after the planning commission's action; ${ }^{111}$ without

105. Id. at 1029-32.

106. Id. at 1031-32.

107. See, e.g., Opinion of the Justices (Public Use of Coastal Beaches), 649 A.2d 604, 610 (N.H. 1994) ("The general public may, therefore, acquire coastal beach land by prescription in New Hampshire.").

108. See, e.g., State ex rel. Thornton v. Hay, 462 P.2d 671, 676-78 (Or. 1969).

109. 526 U.S. 687 (1999).

110. In City of Monterey, the landowner concluded that the city would not permit development of the property "[a]fter five years, nineteen different site plans, and five formal decisions." Id. at 698.

111. In City of Monterey, the courts, including the U.S. Supreme Court, avoided confronting this question because the landowner did not contend that the city's regulations were unreasonable as applied to its property, but instead argued that "the city's denial of the final development 
these determinations, both of which rest on state law, the court has no basis for determining whether the commission's action violated constitutional protections.

Of course, whenever the Court confronts a constitutional challenge to a state statute or regulation, the Court must ascertain the content of state law. But once the Court ascertains that content, the Court's focus shifts to its own constitutional standards, not to an examination of state law before enactment of the challenged statute. Consider Virginia $v$. Black, in which the Court faced a First Amendment challenge to a Virginia criminal statute prohibiting cross burning with intent to intimidate. ${ }^{12}$ Before invalidating the statute's provision that "[a]ny such burning of a cross shall be prima facie evidence of an intent to intimidate," the Court investigated Virginia law to ascertain that the provision would allow a jury to convict even if the state were to offer no evidence of intent to intimidate. ${ }^{113}$

Once the Court determined the meaning of the Virginia statute, however, further examination of Virginia law was unnecessary. The law of Virginia before enactment of the cross-burning statute would have been irrelevant to the Court's analysis. Instead, the Court's opinion could focus on its own First Amendment decisions and determine whether the Virginia statute conflicted with the First Amendment principles the Court had developed. By contrast, in a takings case, the Court cannot determine whether the regulation has gone "too far" without locating the landowner's preexisting development rights. However difficult that determination may be for a state court familiar with local processes, it would be much more oppressive for the U.S. Supreme Court, which is unlikely to have significant experience with the development process in any individual state.

\section{Guidance}

At the same time that dependence on state law increases the burden facing the Supreme Court as it decides a takings case, it also reduces the value of the Court's resulting opinion. The guidance the Court's opinions provide to planners, and to state courts and lower federal courts, is severely limited if those opinions depend too heavily on background state law.

Recent decades have brought increasing agreement that the Supreme Court's most important mission is to implement the Federal Constitution

permit was inconsistent not only with the city's general ordinances and policies but even with the shifting ad hoc restrictions previously imposed by the city." Id. at 722 .

112. 538 U.S. $343(2003)$.

113. Id. at 363, 363-64 (quoting VA. CoDE ANN. $\S 18.2-423$ (Michie 1996)) (alteration in original). 
rather than simply to decide constitutional cases. ${ }^{114}$ The Court's position at the apex of the judicial pyramid enables it to allocate constitutional responsibilities among a variety of institutions and to provide guidance about how those responsibilities should be exercised. ${ }^{115}$ The Court's guidance function has become so important that constitutional doctrine emerges less from incremental responses to new fact patterns and more from the Court's articulation of abstract constitutional principles. ${ }^{116}$ For many (including some members of the Court, most notably Justice Scalia), the ideal opinion sets forth clear rules to guide lower courts and other decisionmakers. ${ }^{117}$

The Court's acceptance of a rule-based jurisprudence, however, has been far from complete, in part, no doubt, due to the rule skepticism of

114. See Richard H. Fallon, Jr., The Supreme Court, 1996 Term-Foreword: Implementing the Constitution, 111 HARV. L. REV. 54, 57 (1997) ("Identifying the 'meaning' of the Constitution is not the Court's only function. A crucial mission of the Court is to implement the Constitution successfully. In service of this mission, the Court often must craft doctrine that is driven by the Constitution, but does not reflect the Constitution's meaning precisely."). Scholars and judges of very different stripes have focused their efforts on how the Court can best implement the Constitution. Some - most notably Cass Sunstein - have argued that the Court can do so by deciding as little as possible in each case before it, thus promoting greater deliberation in the democratic branches. CASS R. SUNSTEIN, ONE CASE AT A TIME: JUDICIAL MINIMALISM ON THE SUPREME COURT 24-32, 53-54 (1999). Justice Scalia is perhaps Sunstein's polar opposite, arguing that the Court should "establish[] as soon as possible a clear, general principle of decision." Antonin Scalia, The Rule of Law as a Law of Rules, 56 U. CHI. L. REV. 1175, 1179 (1989). Both Sunstein and Scalia focus, albeit in different ways, on how the Court can implement a constitutional vision.

115. See Harold J. Krent, The Supreme Court as an Enforcement Agency, 55 WASH. \& LEE L. REV. 1149, 1150 (1998) (emphasizing the Court's need to consider the impact of its decisions on other decisionmakers and stating that "[t]he Court must assess how best, given its limited resources, to control, or at least to influence, constitutional interpretation by others"); see also Scalia, supra note 114, at 1178-79 (emphasizing the importance of clear Supreme Court rules in a pyramidal structure where, without such rules, lawmaking would largely be left to thirteen courts of appeals); $c f$. Evan H. Caminker, Precedent and Prediction: The Forward-Looking Aspects of Inferior Court Decisionmaking, 73 TEX. L. REV. 1, 16-17 (1994) (noting the role of lower courts in facilitating access to the Supreme Court's edicts).

116. See Ashutosh Bhagwat, Separate but Equal?: The Supreme Court, the Lower Federal Courts, and the Nature of the "Judicial Power," 80 B.U. L. REV. 967, 994 (2000).

The Supreme Court does not have the capacity to decide more than a fraction of the takings cases that reach the state and federal courts. As Justice Scalia observed nearly fifteen years ago, "the number of federal cases heard by [the Supreme] Court represented just about one-twentieth of one percent of all the cases decided by federal district courts." Scalia, supra note 114, at 117879. The Supreme Court's caseload as a percentage of cases decided by the state courts was far smaller. And, since Justice Scalia wrote in 1989, the Court's docket has shrunk. See Michael E. Solimine, Supreme Court Monitoring of State Courts in the Twenty-First Century, 35 IND. L. REV. 335, 358-59 (2002).

117. See, e.g., Scalia, supra note 114, at 1179. See generally Louis Kaplow, Rules Versus Standards: An Economic Analysis, 42 DUKE L.J. 557, 612-614 (1992) (discussing the heavy economic costs of postponing establishment of precedent that will guide future activity). But see SUNSTEIN, supra note 114, at 234-43 (discussing circumstances in which broad rules do not generate significant advantages). 
judges trained in the common law method. ${ }^{118}$ Much of the Court's guidance comes in the form of balancing tests of one sort or another-standards rather than hard-and-fast rules. 119 These standards generally provide less guidance than rules, but at least in purely federal cases, the standards provide a tolerable road map for other decisionmakers. Consider for instance, Gratz v. Bollinger ${ }^{120}$ and Grutter v. Bollinger. ${ }^{121}$ The Court's opinions do not draw clear lines between affirmative action policies that are constitutionally permissible and those that are not. Nevertheless, if a public law school chooses to copy the policy implemented by the University of Michigan Law School and deemed permissible by the Court in Grutter, the law school can be reasonably confident that its policy will be upheld. Moreover, even if an institution were not to copy precisely the Michigan Law School policy, the two opinions provide state and federal courts with a reasonable, if imperfect, basis for determining whether the implemented policy would violate federal constitutional limits.

In takings cases, however, Supreme Court opinions have significantly less potential for providing guidance to lower courts and other decisionmakers. Takings opinions generate reduced guidance even when the Court imposes categorical rules, but the problem is exacerbated when the Court proceeds by applying balancing tests. ${ }^{122}$ In the typical constitutional case, any balancing test the Court develops will rest on federal constitutional values that do not vary with the content of state law. Application of the test may require consideration of the particular interests reflected in state law, but the Court's articulation of federal constitutional values will guide decisionmakers in every state. To take a recent example, in Sell v. United States, the Court reversed a judgment permitting the government to administer antipsychotic drugs to a criminal defendant to assure that he would be competent to stand trial for a nonviolent offense. ${ }^{123}$ In the course of its opinion, the Court held that criminal defendants enjoy a constitutionally protected liberty interest against the forced administration of antipsychotic drugs. The Court then specified the circumstances under

118. See Ernest Young, Rediscovering Conservatism: Burkean Political Theory and Constitutional Interpretation, 72 N.C. L. REV. 619, 682-97 (1994) (detailing Burkean skepticism about grand abstract theories and suggesting that much of constitutional adjudication reflects that skepticism).

119. For a discussion of different sorts of balancing, see Fallon, supra note 114, at 77-83. For a general discussion of balancing tests, see T. Alexander Aleinikoff, Constitutional Law in the Age of Balancing, 96 YALE L.J. 943 (1987).

120. 539 U.S. 244 (2003).

121. 539 U.S. 306 (2003).

122. Kathleen Sullivan has noted that in general, categorization as a style of Supreme Court decisionmaking is rule-like, while balancing is standard-like. Kathleen M. Sullivan, The Supreme Court, 1991 Term-Foreword: The Justices of Rules and Standards, 106 HARV. L. REV. 22, 5962 (1992).

123. 539 U.S. $166(2003)$. 
which the government-presumably either state or federal-could interfere with that interest to assure competence to stand trial: Important government interests must be at stake in bringing the defendant to trial, involuntary medication must significantly further those interests and be necessary to further those interests, and administration of the drugs must be medically appropriate. ${ }^{124}$ Note that each of these inquiries could be performed with respect to any state statute and any particular criminal defendant; the standards developed do not depend in any way on the particular state or federal law governing administration of antipsychotic drugs.

By contrast, in takings cases, the federal constitutional interests vary with underlying state law. The Court has recognized as much in the leading case to apply a balancing approach-Penn Central Transportation Co. $v$. City of New York. ${ }^{125}$ In Penn Central, the Court rejected a claim by the owner of Grand Central Terminal that New York City's Landmarks Preservation Law, as applied by the city's Landmarks Preservation Commission, had worked a taking of its property. In reaching that conclusion, however, the Court emphasized the "ad hoc, factual inquiries" upon which takings jurisprudence rests and identified several factors of significance-starting with " $[t]$ he economic impact of the regulation on the claimant and, particularly, the extent to which the regulation has interfered with distinct investment-backed expectations." ${ }^{26}$ But that impact and those expectations are derived, in large measure, from background state law. In Penn Central itself, Grand Central Terminal was already the subject of municipal beneficence in the form of a tax exemption. ${ }^{127}$ The Landmarks Preservation Law, which the landowner had chosen not to challenge on its face, had resulted in the designation of more than 400 other landmarks throughout the city. ${ }^{128}$ A provision in the landmarks ordinance granted to the owners of landmarked sites transferable development rights (which, in the case of Grand Central, authorized more intensive development of some of the most valuable properties in midtown Manhattan). ${ }^{129}$ The Court discussed all of these background conditions and expressly relied on some of them in the course of rejecting Penn Central's claim that the law had singled it out for unfavorable treatment. ${ }^{130}$ How much guidance, then, did

124. Id. at $180-81$.

125. 438 U.S. 104 (1978).

126. Id. at 124 .

127. Id. at 118 .

128. Id. at 134 .

129. Id. at 113-15.

130. Thus, the Court used the regulation of 400 landmarks to establish that the owners of the terminal had been benefited as well as burdened by the landmark restrictions. Id. at 134-35. The Court also concluded that the transferable development rights mitigated the financial burdens on the landowner and were therefore "to be taken into account in considering the impact of regulation." Id. at 137. 
Penn Central provide for planners or courts considering the validity of a landmarks ordinance in a much smaller municipality, with many fewer landmarks - perhaps only two or three? Penn Central hardly serves as a blueprint for a municipality or a court seeking to conform to constitutional doctrine.

Even when the Court resorts to categorical rules rather than a balancing approach, the Court's opinions generally provide more limited guidance on takings issues than on other constitutional issues. The problem is that even categorical rules must vary with state law. In Lucas v. South Carolina Coastal Council, for instance, the Court articulated a rule that a regulation that deprives a parcel of all economic value constitutes a per se taking. ${ }^{131}$ Such a rule, on its face, provides guidance across state lines. But the Lucas doctrine includes an important and necessary qualification that reduces its nationwide value: Compensation need not be paid if common law nuisance doctrine (a product of state law) would preclude a landowner from developing her parcel. ${ }^{132}$

The greater the level of abstraction with which the Court sets forth takings principles, the less dependent those principles are on state law. Thus, if we treat the Lucas principle as one that requires compensation for regulations that deprive a landowner of all economically valuable use of land, except in cases of nuisance, the principle itself does not depend on the law of any individual state. Similarly, Dolan v. City of Tigard establishes that an exaction of money or property, when required as a condition for new development, must be "related both in nature and extent to the impact of the proposed development." ${ }^{\text {"133 }}$ The statement of this principle includes no reference to state law. But as the Court's principles become more abstract, they also provide less guidance in deciding concrete cases; state courts and lower federal courts will have to examine both challenged actions and background state laws to determine whether the actions meet constitutional standards.

None of the preceding discussion is meant to imply that the Supreme Court's takings decisions provide no guidance to lower courts or other decisionmakers. Instead, the discussion explains why takings decisions provide relatively less guidance than the Court's decisions in other areas of constitutional law. Given the Court's broad discretion over its caseload, one would expect a Court for which guidance is a primary concern to hear

131. See 505 U.S. 1003, 1015 (1992).

132. Id at $1029,1028-29$ (holding that regulations that prohibit all economically beneficial use of land are subject to preexisting limitations on a landowner's title and that such limitations "must inhere in the title itself, in the restrictions that background principles of the State's law of property and nuisance already place upon land ownership").

133. 512 U.S. 374, 391 (1994). 
relatively fewer takings cases and to concentrate its efforts in areas where guidance might be more valuable.

\section{Uniformity}

Providing guidance to decisionmakers is one aspect of a larger Supreme Court objective: assuring uniform application of constitutional values. ${ }^{134}$ Guidance advances that objective by instructing local, state, and federal institutions about constitutional standards, but the principle that similarly situated litigants should be treated equally retains force apart from the instructions decisionmakers have received about constitutional norms or values. $^{135}$

With respect to constitutional rights dependent on state law, however, complete uniformity is a more complex objective. On an abstract, general level, the Court can subject all statutes and regulations to the same constitutional principles. For instance, in every state, regulations that go "too far" are unconstitutional takings. But as the level of particularity increases, complete uniformity becomes impossible to achieve. A statute or regulation enacted in one jurisdiction might pass constitutional muster even though an identical statute in another jurisdiction has proven constitutionally infirm - all because of a difference in background state law. ${ }^{136}$ If uniformity means assuring that regulations identical on their face receive identical constitutional treatment, uniformity has no place in takings doctrine.

Even if particular regulations receive different treatment depending on the content of background law, the quest for uniform application requires that constitutional principles be applied in an evenhanded way. And the prospect of Supreme Court review may be helpful, and sometimes necessary, to ensure that decisionmakers conscientiously follow the Court's directions. ${ }^{137}$

How much Supreme Court review is appropriate to police state and local decisionmakers may vary with the constitutional provision at issue. Takings scholars have often focused on breakdowns in the political process as a primary justification for judicial review. ${ }^{138}$ Especially at the local level, land use decisions may impose externalities on neighbors and on outsiders not represented in the local political process. In addition, land use planning

134. See Caminker, supra note 115 , at $38-39$ (identifying the predictability of legal obligations as one objective advanced by uniformity of national law).

135. Id. at 39.

136. See supra text accompanying notes $81-91$.

137. See O'Connor, supra note 77 , at 4 (noting the importance of ensuring that state courts "conscientiously follow the constructions of federal law adopted by the Supreme Court").

138. See supra note 62 (discussing process theorists). 
is often the most important function delegated to local governments. ${ }^{139}$ As a result, the opportunities for coalition building may be few, increasing the likelihood that permanent factions will develop and resulting in the oppression of minorities. ${ }^{140}$ The same problem may develop with respect to land use decisions made by limited-purpose state agencies, such as the coastal councils whose decisions were at stake in Nollan ${ }^{141}$ and Lucas. ${ }^{142}$ Judicial review is one mechanism for disciplining local officials and protecting landowners against political process failures.

This justification for judicial review, however, is not necessarily a justification for Supreme Court review. State judges are typically more familiar with local conditions, problems, and background state law than is the Supreme Court. ${ }^{143}$ And the necessary dependence of takings doctrine on background state law makes the hope of nationwide uniformity little more than a chimera. Why not, then, rely on state courts to protect against political process failures?

Over the past quarter-century, debate has raged over the relative capacity of state and federal courts to adjudicate federal constitutional claims. Beginning with Burt Neuborne's The Myth of Parity, ${ }^{144}$ a number of scholars have argued that state judges labor under institutional disadvantages that make them ill suited for resolution of federal constitutional claims. ${ }^{145}$ The arguments have focused first on the greater political accountability of state judges, ${ }^{146}$ many of whom are elected or appointed for fixed terms rather than for life, ${ }^{147}$ and second on the alleged

139. See Robert C. Ellickson, Suburban Growth Controls: An Economic and Legal Analysis, 86 YALE L.J. 385, 405-06 (1977).

140. Id. at 405; see also Carol M. Rose, Planning and Dealing: Piecemeal Land Controls as a Problem of Local Legitimacy, 71 CAL. L. REV. 837, 855-57 (1983).

141. Nollan v. Cal. Coastal Comm'n, 483 U.S. 825 (1987).

142. Lucas v. S.C. Coastal Council, 505 U.S. 1003 (1992).

143. By the same token, state courts are not constrained by federalism concerns that might make the Supreme Court reluctant to regulate government activity in all fifty states, especially when the Court has a limited understanding of local context. See Robert A. Schapiro, Identity and Interpretation in State Constitutional Law, 84 VA. L. REV. 389, 430 (1998).

144. Burt Neuborne, The Myth of Parity, 90 HARV. L. REV. 1105 (1977).

145. See, e.g., Martin H. Redish, Judicial Parity, Litigant Choice, and Democratic Theory: A Comment on Federal Jurisdiction and Constitutional Rights, 36 UCLA L. REV. 329, 333-34 (1988) [hereinafter Redish, Judicial Parity]; Martin H. Redish, Reassessing the Allocation of Judicial Business Between State and Federal Courts: Federal Jurisdiction and "The Martian Chronicles," 78 VA. L. REV. 1769, 1779-81 (1992); Michael Wells, Is Disparity a Problem?, 22 GA. L. REV. 283, 300 (1988).

146. See, e.g., Neuborne, supra note 144, at 1127-28; Redish, Judicial Parity, supra note 145 , at $333-34$.

147. See generally Polly J. Price, Selection of State Court Judges, in STATE JUDICIARIES AND IMPARTIALITY: JUDGING THE JUDGES 9 (Roger Clegg \& James D. Miller eds., 1996) (analyzing methods of the selection of state judges). 
psychological affinity between state judges and other state officials. ${ }^{148}$ Others have offered a variety of responses: Differences in political accountability are more theoretical than practical; state court systems differ so much from each other that generalization is dangerous; ${ }^{149}$ and political accountability lends legitimacy to constitutional adjudication by state courts. ${ }^{150}$ Many of the debate's protagonists concede the futility of efforts to resolve the debate empirically. ${ }^{151}$

Whatever impact political accountability and psychological affinity might have on state judges when they evaluate hot-button federal constitutional claims, there is little reason to think these factors play a significant role in adjudication of the local development controversies that generate takings claims. Because developers and local governments are both active in local politics, it is not clear in what direction-if anypolitical accountability would skew state judicial supervision of the land use process. Takings questions are a far cry from free speech or equal protection controversies that typically pit a disenfranchised individual with an unpopular cause against the power of the state. ${ }^{152}$ Similarly, if one views state judges generally as members of a "propertied" class, it is difficult to

148. See Neuborne, supra note 144, at 1120-21 (discussing the psychological set of state judges); Robert A. Schapiro, Polyphonic Federalism: State Constitutions in the Federal Courts, 87 CAL. L. REV. 1409, 1439-40 (1999); Wells, supra note 145, at 300. But cf. Erwin Chemerinsky, Ending the Parity Debate, 71 B.U. L. REv. 593, 599 (1991) [hereinafter Chemerinsky, Ending the Parity Debate] ("[S]tate court judges generally have some degree of insulation by virtue of features such as long terms, a tradition of non-partisanship and strong support for incumbent judges, and non-contested retention elections. A survey of twenty years of election data from 1964 to 1984 found that in 1,864 judicial elections, only twenty-two judges $(1.2 \%)$ were defeated. Electoral accountability only undermines state judicial independence if state court judges fear that voters will use their decisions as the basis for casting their votes. But how many cases are of sufficient visibility to influence voters?" (footnotes omitted)); Erwin Chemerinsky, Parity Reconsidered: Defining a Role for the Federal Judiciary, 36 UCLA L. REV. 233, 255-80 (1988).

149. See, e.g., Ann Althouse, Tapping the State Court Resource, 44 VAND. L. REV. 953, 95859 (1991) (noting the diversity of state courts and of state judges); Chemerinsky, Ending the Parity Debate, supra note 148 , at 600 (noting differences among state courts and the uselessness of aggregate comparisons of state and federal courts).

150. See Nathan S. Heffernan, Judicial Responsibility, Judicial Independence and the Election of Judges, 80 MARQ. L. REV. 1031, 1046, 1046-47 (1997) (noting that "the election process affords the Wisconsin judiciary some legitimacy as a co-equal branch of government," emphasizing the credibility advantages elected judges have in dealing with other branches of government, and asserting that the Wisconsin Supreme Court refused to enforce the Fugitive Slave Law while the United States Supreme Court did enforce it).

151. See, e.g., Chemerinsky, Ending the Parity Debate, supra note 148, at 599-600; Burt Neuborne, Parity Revisited: The Uses of a Judicial Forum of Excellence, 44 DEPAUL L. REV. $797,798(1995)$.

152. Indeed, William Rubenstein has argued that the need to remain connected with politics sometimes makes state courts more receptive to rights-based claims than federal courts, simply because politics keeps judges in touch with problems faced by significant minority groups. Rubenstein argues in particular that gay rights advocates often prefer state court litigation for that reason. William B. Rubenstein, The Myth of Superiority, 16 CONST. COMMENT. 599, 619-21 (1999). 
argue that their affinity will naturally and consistently lie with government decisionmakers rather than with aggrieved landowners. As a result, there would appear to be little institutional reason to conclude that state courts are poorly situated to police political process failures in the takings area.

An independent uniformity-based justification for Supreme Court review would rest on the possibility that a particular state or group of states might reject the premises behind a constitutional right or value. Consider, as illustrations, abortion rights in the Bible Belt, the right to bear arms in urban states, or equal protection in the South before the civil rights movement. In each case, legislation that transgresses constitutional limits might not rest on any process failure, but simply on local disagreement with norms that otherwise enjoy national acceptance. To the extent that state courts reflect state values, state courts might not adequately safeguard constitutional rights. In instances like these, Supreme Court review might be necessary to assure uniform enforcement of federal rights.

There is little reason to invoke this justification in takings cases. The Takings Clause protects against changes in property rights, or, in the Court's words, against interference with "investment-backed expectations." 153 Assume a state whose culture is hostile to such protection, a state in which development rights are commonly viewed as "up for grabs." This culture is reflected in common law doctrine that makes investment in property somewhat risky. The culture is also reflected in legislation that warns prospective owners of "property" that their rights are subject to redefinition in service of the public interest. One would expect the courts of such a state to be hostile to takings claims. But in such a state, the value of property "rights" would always have been heavily discounted to reflect the risk of redefinition. And if background state law is so hostile to the institution of property, landowners would have few investmentbacked expectations worthy of protection. ${ }^{154}$

To summarize, a desire to assure uniform application of the Takings Clause provides little justification for active Supreme Court review of takings cases. First, no theoretical obstacles prevent state courts from policing abuses of the political process. Second, the dependence of takings doctrine on state law makes uniformity a somewhat unrealistic goal in any

153. Penn Cent. Transp. Co. v. City of New York, 438 U.S. 104, 124 (1978).

154. One might hypothesize, of course, a sea change in the culture and politics of a particular state-the electorate replaces a longstanding pro-property regime with a regime bent on redistribution, for example. But even in that unlikely event, the case for Supreme Court review rests on the assumption that this sea change has swept in not merely new executives and legislatures (at the state and local levels), but also a new judiciary-despite the protections of judicial independence included in most state constitutions. Moreover, the chance of a cultural revolution that infects only a single state seems a slender reed on which to build a theory of Supreme Court review. 
event. Finally, to the extent that state courts reflect local attitudes about property rights, those courts should adequately safeguard those rights even without intensive Supreme Court oversight.

\section{DOCTRINAL IMPLICATIONS}

Supreme Court review is a scarce resource. Time spent reviewing any case or category of cases reduces the time available for consideration of other cases and categories. Section II.C established that Supreme Court takings opinions provide limited guidance and have little potential for generating uniformity. As a result, one would expect the Court to hear and decide few takings cases and to rely largely on state courts to police the land use process. And, indeed, for several decades preceding Penn Central, the Court largely followed this model-hearing few challenges to land use regulations and sustaining none of them. ${ }^{155}$

Avoidance of takings cases is not, however, the only model consistent with the Court's limited potential for providing guidance and assuring uniformity. Supreme Court guidance is of limited value because takings law is dependent on state law. But at some level of generality, the Court could articulate rules and principles independent of state law. Justice Holmes's oft-quoted statement that "if regulation goes too far it will be recognized as a taking" 156 furnishes an example. The principle that regulation and physical takings should not be viewed as airtight boxes is not dependent on state law. The principle certainly provided guidance to courts that might otherwise have held-based on earlier Supreme Court precedent ${ }^{157}$ - that regulation could never amount to a taking, no matter how significant the change in landowners' rights. The point is that the Court could develop some broad principles, independent of state law, that would serve as touchstones for analysis by lower courts. The Court would not be wasting resources so long as it focused on developing and articulating these principles rather than on monitoring compliance with them.

155. See Marilyn F. Drees, Do State Legislatures Have a Role in Resolving the "Just Compensation" Dilemma? Some Lessons from Public Choice and Positive Political Theory, 66 FORDHAM L. REV. 787, 791 (1997) (noting that after the 1928 invalidation of a zoning ordinance in Nectow v. City of Cambridge, "the Court did not take up the regulation of real property again for nearly half a century"); Molly S. McUsic, The Ghost of Lochner: Modern Takings Doctrine and Its Impact on Economic Legislation, 76 B.U. L. REV. 605, 625 n.85 (1996) (noting that between 1937 and 1979, "the Court never decided a regulatory takings claim in favor of the property owner").

156. Pa. Coal Co. v. Mahon, 260 U.S. 393, 415 (1922).

157. See, e.g., Mugler v. Kansas, 123 U.S. 623, 668-69 (1887). See generally Treanor, supra note 23 , at 832-36 (noting that in the pre-Pennsylvania Coal era, regulations were sustained if they were aimed at promoting health, safety, or morals, regardless of harm to individuals). 
This Part demonstrates that over the last twenty-five years, the Court's takings jurisprudence has largely followed this course. The Court has focused on developing categorical rules that apply to takings claims without regard to underlying state law. The Court has invalidated land use regulations only when it could do so by reference to a categorical rule. In other cases, where the Court has been unable to state a categorical rule, it either has applied a balancing test (which inevitably results in sustaining the challenged regulation) or has determined that the constitutional claim was not ripe for adjudication.

In some ways, this pattern looks similar to the approach the Supreme Court takes in other areas of constitutional law: The Court sets forth a combination of categorical rules and balancing tests and leaves much of the administration to the states and the lower federal courts. In fact, however, the Court's takings cases display critical differences. First, the Court has developed a ripeness doctrine that significantly limits the role of the lower federal courts in adjudicating takings claims. As a result, state courts play the primary role in the administration of takings doctrine. Second, whenever the Court applies a balancing test to a state enactment, the Court upholds the enactment; the balancing, at least at the Supreme Court level, is more theoretical than real. Third, despite the dependence of takings law on state law, the only categorical rules the Court has adopted operate independently of state law. The result has been that, however onerous a state or local regulation may be, the Court does not strike it down unless it can agree on application of a categorical rule that transcends the differences among the property laws of the several states.

Whether the Court's current approach is preferable to the previous model-essentially one of abstention from hearing and deciding takings cases-is beyond my current concern. Instead, this Part seeks to establish that even with the categorical rules the Court has formulated, state courts remain substantially free to fashion takings doctrine in ways that respond to local concerns. The Court's categorical rules operate to remove from the state courts only a little of the regulatory freedom those courts would have enjoyed if the Court had remained silent for the last quarter-century.

\section{A. Ripeness and the Role of Inferior Federal Courts}

In an important category of takings cases, the Court has declined to reach the merits of claims on the ground that the claims are not yet ripe for adjudication. In recent years, the Court's ripeness doctrine has been instrumental in reducing the role of all federal courts in adjudicating takings cases. 
The Court developed its current ripeness doctrine in a series of cases that avoided deciding whether the states were constitutionally obligated to provide a damages remedy for unconstitutional takings--the issue the Court ultimately resolved in First English Evangelical Lutheran Church v. County of Los Angeles. ${ }^{158}$ The ripeness doctrine was developed most completely in Williamson County Regional Planning Commission $v$. Hamilton Bank. ${ }^{159}$ After the planning commission disapproved the landowner's subdivision plat, the landowner brought a $\S 1983$ action in federal court alleging that the commission had taken its property without just compensation. ${ }^{160}$ After a jury awarded the landowner $\$ 350,000$ in damages, the federal district judge issued an injunction requiring approval of the plat but granted the commission a judgment notwithstanding the verdict on the takings claim, holding that a temporary deprivation cannot constitute a taking. ${ }^{161}$ The Sixth Circuit reversed, holding that a temporary denial of property should be analyzed in the same way as a permanent taking. ${ }^{162}$ The Supreme Court granted certiorari to resolve whether the government must pay damages for a temporary taking. ${ }^{163}$

The Supreme Court did not, however, reach that issue on the merits, holding instead that the claim was not yet ripe. In reaching that conclusion, the Court established that a takings claim must surmount two obstacles. First, a landowner must establish that it has obtained "a final decision regarding how it will be allowed to develop its property." 164 The Court reasoned that the factors relevant to a takings inquiry "simply cannot be evaluated until the administrative agency has arrived at a final, definitive position regarding how it will apply the regulations at issue to the particular land in question." 165 And because the landowner did not seek variances

158. 482 U.S. 304 (1987).

159. 473 U.S. 172 (1985). The Court first developed the doctrine in San Diego Gas \& Electric Co. v. City of San Diego, 450 U.S. 621 (1980). The landowner had brought an action in the Califomia courts seeking damages for an alleged taking resulting from the city's enactment and application of its zoning ordinance. The California Court of Appeal rejected the landowner's claim for money damages, indicating that the landowner's only remedy would be mandamus or declaratory relief. Id. at 629-30 (relying upon Agins v. City of Tiburon, 598 P.2d 25 (Cal. 1979), aff'd, 447 U.S. 255 (1980)). At the same time, however, that court noted the existence of disputed factual issues that the trial court could deal with anew should the landowner "elect to retry the case." Id. at 630. The California Supreme Court denied further review, and the landowner appealed to the U.S. Supreme Court, alleging that the California courts' refusal to provide a damages remedy violated the Federal Constitution. Id. The Supreme Court, however, dismissed the appeal, concluding that the decision of the California Court of Appeal was not final because that court had not decided whether any taking had occurred. Id. at 633.

160. Williamson County, 473 U.S. at 182.

161. Id. at 183 .

162. Id at 183-84.

163. Id. at 185 .

164. Id. at 190 .

165. Id. at 191 . 
from the applicable regulations, it would be impossible to determine whether the landowner would be able to derive economic benefit from the land. ${ }^{166}$ The second ripeness obstacle the Court set forth is the requirement that landowners seek compensation via the state's procedures. ${ }^{167}$ The Court emphasized that "[i]f the government has provided an adequate process for obtaining compensation, and if resort to that process yield[s] just compensation," the landowner cannot claim a violation of the Takings Clause until the landowner has "used the procedure and been denied just compensation." 168

Although the framework developed in Williamson County was initially designed to avoid the question resolved two years later in First English, ${ }^{169}$ it survived the decision in Firsi English that states must provide a damages remedy for unconstitutional takings. Thus, in Suitum v. Tahoe Regional Planning Agency, the Court reaffirmed the existence of "two independent prudential hurdles to a regulatory takings claim brought against a state entity in federal court." 170

The Williamson County framework makes it extraordinarily difficult for a disappointed landowner to litigate takings issues in federal court. In applying the ripeness doctrine, the federal courts of appeals have typically found $\S 1983$ actions unripe for failure to give the municipality an adequate opportunity to indicate what development would be permitted ${ }^{171}$ or for failure to seek compensation through state processes. ${ }^{172}$ Moreover, the federal courts have not generally permitted landowners to avoid the

166. Id.

167. Id. at 194 .

168. Id. at 194-95 (second alteration in original) (internal quotation marks omitted). The landowner in Williamson County had argued that because it had brought its action pursuant to $\S 1983$, the claim was not subject to a requirement that the landowner exhaust administrative remedies. Therefore, the landowner argued, failure to seek a variance did not make its claim premature. In a critical passage, however, the Court explicitly rejected the landowner's argument, concluding that "whether administrative remedies must be exhausted is conceptually distinct ... from the question whether an administrative action must be final before it is judicially reviewable." Id. at 192. Hence, even in an action brought pursuant to $\S 1983$, the landowner's failure to seek a variance precluded relief because it had not met the finality requirement that, the Court held, was applicable to $\S 1983$ actions.

169. The Court in Williamson County conceded that it had granted certiorari to decide the damages question, acknowledged that it had twice left the issue undecided, and concluded that the issue should be left for another day because the landowner's claim was premature. Id. at 185 . Only a year later, the Court again invoked the Williamson County ripeness doctrine to avoid reaching the damages issue. MacDonald, Sommer \& Frates v. County of Yolo, 477 U.S. 340, $351-53(1986)$.

170. 520 U.S. 725, 733-34 (1997).

171. See, e.g., Signature Props. Int'l Ltd. P'ship v. City of Edmond, 310 F.3d 1258 (10th Cir. 2002); Bateman v. City of W. Bountiful, 89 F.3d 704 (10th Cir. 1996); Southview Assocs., Ltd. v. Bongartz, 980 F.2d 84 (2d Cir. 1992).

172. See, e.g., Johnson v. City of Shorewood, 360 F.3d 810 (8th Cir. 2004); Carson Harbor Vill., Ltd. v. City of Carson, 353 F.3d 824 (9th Cir. 2004); Sandy Creek Investors, Ltd. v. City of Jonestown, 325 F.3d 623 (5th Cir. 2003); Cowell v. Palmer Twp., 263 F.3d 286 (3d Cir. 2001). 
ripeness problem by styling their claims as substantive due process claims rather than as takings claims. ${ }^{173}$ Landowners have sometimes avoided the ripeness bar by styling their claims as equal protection ${ }^{174}$ or First Amendment ${ }^{175}$ claims or by contending that the government's "taking" was for private use (thus making the action invalid even if the government were willing to pay compensation). ${ }^{176}$ Similarly, if the landowner makes a facial

173. The Tenth Circuit has been most consistent in holding that Williamson County's ripeness requirements apply equally to takings claims and substantive due process claims. See Signature Props., 310 F.3d at 1268 (noting that a different standard for due process claims would "emasculate the finality requirement entirely"); see also Landmark Land Co. v. Buchanan, 874 F.2d 717, 722 (10th Cir. 1989). The Sixth and Seventh Circuits have taken the same position. See Bowers v. City of Flint, 325 F.3d 758, 762 (6th Cir. 2003) (involving substantive, but not procedural, due process claims subject to Williamson County's finality requirement); Forseth v. Vill. of Sussex, 199 F.3d 363, 370 (7th Cir. 2000) (involving substantive due process claim "subject to Williamson's requirement that [claimants] seek a final decision and pursue state court remedies before federal courts have jurisdiction to hear their case").

The Ninth and Eleventh Circuits have simply concluded that substantive due process does not apply when a more specific constitutional protection-the Takings Clause--protects against the challenged government action. Hence, the only claim a landowner can generally bring-a takings claim-would be subject to the Williamson County ripeness requirements. See Macri v. King County, 126 F.3d 1125, 1128-29 (Gth Cir. 1997); Villas of Lake Jackson, Ltd. v. Leon County, 121 F.3d 610, 612-14 (11th Cir. 1997); Armendariz v. Penman, 75 F.3d 1311, 1320-24 (9th Cir. 1996); see also Deniz v. Municipality of Guaynabo, 285 F.3d 142, 149 (1st Cir. 2002) ("Dressing a takings claim in the raiment of a due process violation does not serve to evade the exhaustion requirement."); S. County Sand \& Gravel Co. v. Town of S. Kingston, 160 F.3d 834, 835 (1st Cir. 1998) (concluding that substantive due process claims are subsumed within takings claims but not discussing ripeness issues). The Third Circuit has taken a similar position: A substantive due process challenge to a municipal land use decision must show that defendants' conduct shocked the conscience. See Lindquist v. Buckingham Twp., No. 02-2469, 2003 U.S. App. LEXIS 11351, at*4 (3d Cir. May 16, 2003).

The Second Circuit has divided substantive due process challenges to land use regulations into two categories. The first, those challenges premised on the theory that a regulation has "gone too far," is subject to both Williamson County ripeness hurdles. If, however, the challenge is premised on arbitrary and capricious government conduct, the landowner's complaint is not the adequacy of compensation, and the landowner should not be required to use state processes for obtaining compensation. Therefore, according to the Second Circuit, the landowner has to surmount only the first hurdle. Southview Assocs., 980 F.2d at 96-98; see also Executive 100, Inc. v. Martin County, 922 F.2d 1536, 1540-41 (11 th Cir. 1991) (distinguishing between "due process takings" claims, subject to ripeness requirements, and "arbitrary and capricious due process" claims, not subject to ripeness requirements).

The Fifth Circuit has purported to distinguish between takings claims and substantive due process claims but has acknowledged that ripeness requirements apply to some due process claims, although not those where finality is not an issue, such as a claim that the relevant ordinance is unconstitutionally vague, facially or as applied. See John Corp. v. City of Houston, 214 F.3d 573, 583-85 (5th Cir. 2000).

174. See, e.g., Forseth, 199 F.3d 363; Rolf v. City of San Antonio, 77 F.3d 823 (5th Cir. 1996); Executive 100, 922 F.2d 1536. But see Landmark Land Co., 874 F.2d 717 (applying the ripeness doctrine to an equal protection claim).

175. See, e.g., Carpinteria Valley Farms, Ltd. v. County of Santa Barbara, 344 F.3d 822 (9th Cir. 2003) (involving a claim that the municipality used the planning process to retaliate for the exercise of First Amendment rights); Dougherty v. Town of N. Hempstead Bd. of Zoning Appeals, 282 F.3d 83 (2d Cir. 2002) (involving alleged retaliation for the exercise of First Amendment rights).

176. See, e.g., Daniels v. Area Plan Comm'n, 306 F.3d 445, 456-58 (7th Cir. 2002) (holding Williamson County ripeness requirements inapplicable when a landowner claims a taking is for an 
challenge to an ordinance, alleging that it does not substantially advance legitimate state interests, the claim may be ripe without meeting the Williamson County standards. ${ }^{177}$ These strategies, however, will only be available in limited circumstances and provide little guaranty of success on the merits.

Moreover, a landowner who has pursued all available state remedies faces another potential problem in seeking federal redress: res judicata. Once the state courts have determined that a landowner is not entitled to compensation because the government actions did not constitute a taking, res judicata principles typically bar federal courts from entertaining the same claim in a collateral proceeding. ${ }^{178}$ The Second Circuit, in Santini v. Connecticut Hazardous Waste Management Service, has recently held that plaintiffs may avoid the ordinary res judicata bar if their state court complaints expressly reserve the right to litigate federal constitutional claims in federal court, but the court conceded that most other circuits have been unwilling to recognize such an exception. ${ }^{179}$ The Ninth Circuit has already rejected the Santini position. ${ }^{180}$ More importantly, it is far from

impermissible private purpose, and which caused no monetary loss, so seeking damages through state processes would have been futile); Montgomery v. Carter County, 226 F.3d 758, 766-68 (6th Cir. 2000) (holding that a claim that a taking was for strictly private use was not subject to Williamson County ripeness requirements).

177. See, e.g., San Remo Hotel v. City and County of San Francisco, 145 F.3d 1095 (9th Cir. 1998). The U.S. Supreme Court recently granted certiorari in another case that falls into this category. Chevron USA v. Bronster, 363 F.3d 846 (9th Cir. 2004), cert. granted sub nom. Lingle v. Chevron USA, 2004 U.S. LEXIS 6698 (U.S. Ost. 12, 2004) (No. 04-i63).

178. The federal full faith and credit statute provides that judicial proceedings "shall have the same full faith and credit in every court within the United States and its Territories and Possessions as they have by law or usage in the courts of such State, Territory or Possession from which they are taken." 28 U.S.C. $\S 1738$ (2000). The statute implements the Constitution's Full Faith and Credit Clause, U.S. CONST. art. IV, § 1.

In Allen v. McCurry, 449 U.S. 90 (1980), the Supreme Court construed the statute to require "all federal courts to give preclusive effect to state-court judgments whenever the courts of the State from which the judgments emerged would do so." Id. at 96 . In Allen, the Court held that a state court determination, in a criminal proceeding, that a criminal defendant had not been subjected to an unconstitutional search and seizure precluded the criminal defendant from later bringing a $\S 1983$ proceeding in federal court against the police officers involved. The Court explicitly rejected the "generally framed principle that every person asserting a federal right is entitled to one unencumbered opportunity to litigate that right in a federal district court," finding no support for the principle either in the Constitution or in $\S 1983$ itself. Id. at 103.

Moreover, in Migra v. Warren City School District Board of Education, 465 U.S. 75 (1984), the Court extended Allen to issues that a $\S 1983$ litigant could have raised, but did not actually raise, in state court. Allen and Migra together appear to establish that a litigant who raises a takings claim in state court and loses should then be precluded from pursuing a $\$ 1983$ claim in federal district court on the basis of the same alleged taking. See Wilkinson v. Pitkin County Bd. of County Comm'rs, 142 F.3d 1319 (10th Cir. 1998); Palomar Mobilehome Park Ass'n v. City of San Marcos, 989 F.2d 362 (9th Cir. 1993); Peduto v. City of N. Wildwood, 878 F.2d 725 (3d Cir. 1989).

179. 342 F.3d 118,128 ( $2 \mathrm{~d}$ Cir. 2003) (citing cases).

180. San Remo Hotel v. City and County of San Francisco, 364 F.3d 1088 (9th Cir. 2004). 
clear that Santini is consistent with the Supreme Court's full faith and credit principles. ${ }^{181}$

The consequence of the ripeness doctrine, then, is to locate primary authority for resolving takings claims in the state courts. Supreme Court review remains a theoretical possibility, but, as the next two Sections demonstrate, the Court will intervene only when it can structure a categorical rule of broad application.

\section{B. Categorical Rules}

Over the last quarter-century, the Supreme Court has, in reviewing state court takings decisions, embraced five categorical rules: (1) The state must make money damages available as a remedy for unconstitutional takings; (2) land use exactions imposed as a condition for development must be roughly proportional to the impact of the proposed development; (3) a regulation that denies the landowner all beneficial use of the land constitutes a taking; (4) a permanent physical occupation of land constitutes a taking; and (5) a state may not adopt a per se rule barring a takings claim by any landowners who purchase with notice of a regulation the landowner

181. The notion that a litigant can avoid the operation of res judicata and full faith and credit principles by reserving in the state court proceedings a right to litigate federal claims in federal court derives from the Supreme Court's opinion in England v. Louisiana State Board of Medical Examiners, 375 U.S. 411 (1964). In England, plaintiff-chiropractors brought an action in federal district court challenging, on federal constitutional grounds, the educational requirements of the Louisiana Medical Practice Act. The Court, relying on the abstention doctrine derived from Railroad Commission v. Pullman Co., 312 U.S. 496 (1941), stayed the proceedings to afford the Louisiana courts opportunity to determine whether, as a matter of state law, the educational requirements applied to chiropractors. When Louisiana's courts determined that the statute did apply and was consistent with the Federal Constitution, plaintiffs returned to federal district court. There, they were met with a motion to dismiss on the ground that the Louisiana state courts had resolved all of the disputed issues, including the federal constitutional issue, leaving plaintiffs with no federal recourse except direct appeal to the U.S. Supreme Court. The federal district court granted the motion, and the court of appeals affirmed. In reversing, the U.S. Supreme Court indicated that if a federal district court invokes an abstention doctrine, and the plaintiff then informs the state courts "that he intends, should the state courts hold against him on the question of state law, to return to the District Court for disposition of his federal contentions," the plaintiff should not be barred from litigating his federal claims in federal court. England, 375 U.S. at 421. Conversely, if the plaintiff "unreservedly litigat[es] his federal claims in the state courts although not required to do so," the plaintiff may not "start all over again in the District Court." Id. at $\mathbf{4 1 9 .}$

In Pullman abstention cases like England, however, federal district courts have jurisdiction to hear federal claims but exercise discretion not to hear those claims pending resolution of disputed state claims. By contrast, in takings cases, the federal courts have no jurisdiction until ripeness requirements are met-which requires state court action. It is not at all clear that the Court would extend the England doctrine to this fact situation.

Moreover, the Court's decisions in Stone v. Powell, 428 U.S. 465 (1976), Allen, and Migra marked a change in the Supreme Court's attitude toward state court resolution of federal claims, casting doubt on the long-term survival of the England rule, although the Court did cite the rule with apparent approval in a footnote in the Migra opinion, Migra, 465 U.S. at 85 n.7. 
seeks to challenge. ${ }^{182}$ These rules share a set of common characteristics. First, all but the fourth operate independently of state law, and that fourth rule is dependent only on state recognition of private ownership of land. Second, the rules are all "easy in, easy out" from the Supreme Court's perspective. That is, once the Court articulates the categorical rule, there will be little reason for further Supreme Court involvement; application can be left entirely to state courts. Third, each rule responds directly to an established state court practice conflicting with the purposes that lie behind the Takings Clause. In other words, each of the rules provides some useful nationwide guidance while providing only modest constraints on the development of takings doctrine by other institutions-principally state officials and state courts.

\section{Availability of Money Damages for Takings}

In First English Evangelical Lutheran Church v. County of Los Angeles, the Supreme Court held that a landowner whose property has been "taken" by a land use regulation is entitled to money damages for the time before the final determination that the offending regulation constituted a taking. ${ }^{183}$ The First English rule focuses not on whether a taking has occurred-an issue that requires evaluation of background state law-but on what remedy a landowner may assert once there has been a determination that a taking has occurred. As a result, the First English rule operates independently of background state law.

Moreover, the rule that money damages are available requires no monitoring by the Court. The Court's opinion explicitly left open some significant questions; in particular, it did not indicate how to distinguish the First English situation from "normal delays" in the process of obtaining permits and variances. ${ }^{184}$ But the Court is unlikely to concern itself with resolution of those questions, instead leaving administration of the First

182. David Dana and Thomas Merrill have argued that takings jurisprudence includes a second class of categorical rules, four areas in which compensation is never required: nuisances, conflagrations, forfeitures, and navigation servitudes. DAVID A. DANA \& THOMAS W. MERRILL, PROPERTY: TAKINGS 110-20 (2002). As a matter of prediction, they are undoubtedly correct. In recent decades, however, the Court has not confronted any challenges to state regulation of common law nuisances (unless one includes Lucas in that category), nor has it faced any challenges to state efforts to combat fire by destroying property that might enable the fire to spread. The forfeiture rule, as Dana and Merrill recognize, might not be so categorical; it is far from clear that the Court would sustain takings "formally designated as forfeitures, but judicially understood as substantively something else." Id. at $116 \mathrm{n}$.183. Finally, the navigation servitude rule applies to federal actions, not to actions by the states, eliminating the federalism concerns raised by other takings cases.

183. 482 U.S. 304, 306-07 (1987).

184. Id. at 321; see also id. at 334-35 (Stevens, J., dissenting). 
English rule to the state courts. ${ }^{185}$ The rule was designed to send a single message: Invalidation of the offending ordinance is not a constitutionally adequate remedy for a taking.

Indeed, the Court's opinion in First English responded directly to the position taken by two of the most influential state courts in the countrythe California Supreme Court and the New York Court of Appeals-both of which had explicitly rejected money damages as a remedy for an unconstitutional land use regulation, holding instead that invalidation was an aggrieved landowner's exclusive remedy. ${ }^{186}$ Those holdings at least arguably created incentives for local planners to single out particular landowners for disadvantageous treatment, leading to unfairness, inefficient land use, or both. ${ }^{187}$ That is, the Court adopted the First English rule only after it became clear that the state courts would not ensure an appropriate

185. In First English, the landowner's allegation was that an interim ordinance prohibited reconstruction of buildings in a canyon whose preexisting buildings had been destroyed during a flood. Id. at 308. The interim ordinance was designed to permit a thorough study of potential flooding dangers. See First English Evangelical Lutheran Church v. County of Los Angeles, 258 Cal. Rptr. 893, 902 (Ct. App. 1989). The California courts had dismissed the complaint based on their determination that compensation was never available as a remedy for unconstitutional takings. As a result, the case reached the U.S. Supreme Court without any determination that the interim ordinance was a taking, and the Court, after rejecting the California rule that damages were always unavailable, remanded to the California Court of Appeal. That court concluded that the interim ordinance did not work a taking, and that damages were therefore unavailable. Id. at 903-06. The California Supreme Court denied review, First English Evangelical Lutheran Church v. County of Los Angeles, No. S010941, 1989 Cal. LEXIS 4224 (Aug. 25, 1989), and the U.S. Supreme Court denied certiorari, First English Evangelical Lutheran Church v. County of Los Angeles, 493 U.S. 1056 (1990) (mem.).

The Court's denial of certiorari after remand provided, by itself, little evidence that the Court would leave policing of damages issues to the states. But in Tahoe-Sierra Preservation Council v. Tahoe Regional Planning Agency, 535 U.S. 302 (2002), the Court, in refusing to adopt a per se rule limiting the duration of development moratoria, expressly noted that the interim ordinance at issue in First English had ultimately been upheld, even though it had been in force for six years before it was replaced by a permanent regulation. Id. at $342 \mathrm{n}$.36. In Tahoe-Sierra, the Court emphasized the need for planners to engage in informed decisionmaking, $i d$. at 339 , and expressly indicated that "[f]ormulating a general rule [setting a limit on delays] is a suitable task for state legislatures," id. at 342.

186. In Agins v. City of Tiburon, 598 P.2d 25 (Cal. 1979), aff'd, 447 U.S. 255 (1980), the California Supreme Court, clarifying its earlier opinion in HFH, Ltd. v. Superior Court, 542 P.2d 237 (Cal. 1975), wrote that a landowner aggrieved by an unconstitutional zoning ordinance "may not ... elect to sue in inverse condemnation and thereby transmute an excessive use of the police power into a lawful taking for which compensation in eminent domain must be paid." Agins, 598 P. $2 \mathrm{~d}$ at 28.

At roughly the same time, the New York Court of Appeals held that the Due Process Clause, not the Takings Clause, was the constitutional source of protection against confiscatory land use regulation. As a result, the court concluded that invalidation, not compensation, was the appropriate remedy. See Fred F. French Investing Co. v. City of New York, 350 N.E.2d 381, 385 (N.Y. 1976) ("In all but exceptional cases ... such a regulation does not constitute a 'taking[,'] and is therefore not compensable, but amounts to a deprivation or frustration of property rights without due process of law and is therefore invalid."). For a more extensive discussion of the California and New York cases, see Sterk, supra note 29, at 120-24.

187. See Ellickson, supra note 139, at 437-38 (arguing that damages liability could reduce the inefficiency of monopoly power in a way injunctive relief could not). 
incentive structure for compliance with the command of the Takings Clause. ${ }^{188}$ Even if the First English rule accomplishes its principal instrumental objective- - to assure that planners take greater care to avoid unconstitutional enactments ${ }^{189}$ - the rule does not impose any additional constitutional constraints on planners or state officials. First English leaves substantive constitutional limits unchanged.

\section{Exactions and the Rough-Proportionality Requirement}

Land use regulation typically vests considerable discretion in zoning boards, planning boards, or other administrative agencies. ${ }^{190}$ These bodies often have power to grant or deny permits, or to grant permits subject to conditions designed to ameliorate whatever harms a proposed development might cause. ${ }^{191}$ In recent decades, some jurisdictions have authorized municipalities to condition permits on the dedication of land or payment of money. ${ }^{192}$ The U.S. Supreme Court first addressed these conditions in Nollan v. California Coastal Commission and held that any condition imposed on a development permit must serve the same governmental purpose that would have been advanced if the government had denied the permit outright. ${ }^{193}$ And in Dolan v. City of Tigard, the Court refined the Nollan holding to require that any exaction required as a condition for a permit be roughly proportional, "both in nature and extent, to the impact of the proposed development."194

188. Indeed, subsequent to the Court's decision in First English, a number of state courts have developed doctrines designed to eviscerate the damages remedy. See, e.g., Landgate, Inc. v. Cal. Coastal Comm'n, 953 P.2d 1188, 1190 (Cal. 1998) (holding that First English does not apply when a development prohibition results partly from error by a government agency); Torromeo v. Town of Fremont, 813 A.2d 389, 392 (N.H. 2002) (same); Pheasant Bridge Corp. v. Twp. of Warren, 777 A.2d 334, 344 (N.J. 2001) (finding that damages are not available as a result of the temporary application of an ordinance declared invalid as exceeding municipal zoning authority).

189. As Justice Brennan put it in his dissenting opinion in San Diego Gas \& Electric Co. v. City of San Diego, 450 U.S. 621 (1981), "After all, if a policeman must know the Constitution, then why not a planner?" Id. at 661 n.26 (Brennan, J., dissenting).

190. See generally DANIEL R. MANDELKER, LAND USE LAW $\S 6.41$ (5th ed. 2003) (discussing variances); id. $\S 6.53$ (discussing special exceptions and conditional uses); id. $\S 9.09$ (discussing subdivision controls).

191. See id. $\$ 6.51$, at 6-57 ("Although the Standard Zoning Act and most state zoning acts do not expressly authorize the board of adjustment to attach conditions to variances, the power to do so is recognized everywhere as inherent in the statutory power to grant variances.").

192. See Martin L. Leitner \& Susan P. Schoettle, A Survey of State Impact Fee Enabling Legislation, 25 URB. LAW. 491 (1993). See generally ROBERT C. ELLICKSON \& VICKI L. BEEN, LAND USE CONTROLS 794-96, 799-807 (2d ed. 2000) (discussing a variety of exactions authorized by state law).

193. 483 U.S. 825, 837 (1987) ("[U]nless the permit condition serves the same governmental purpose as the development ban, the building restriction is not a valid regulation of land use but 'an out-and-out plan of extortion."' (quoting J.E.D. Assocs. v. Town of Atkinson, 432 A.2d 12, 14[] (N.H. 1981))).

194. 512 U.S. 374,391 (1994). 
As with First English's money damages requirement, the roughproportionality rule does not depend on background state law. However much discretion state law gives to decisionmakers, Nollan and Dolan establish that the decisionmakers may only condition a favorable exercise of discretion on an exaction if the exaction is roughly proportional to the harms that would permit the decisionmakers to exercise their discretion unfavorably.

Having announced the rough-proportionality standard in Dolan, the Court appears unlikely to refine it further. The Court signaled as much by emphasizing that "[n]o precise mathematical calculation is required." 195 Rather than monitoring compliance with the standard, the Court appears content to leave implementation to the state courts-many of which had already embraced the Court's position ${ }^{196}$ and others of which had exceeded the Court's mandate. ${ }^{197}$

Here again, the Court's articulation of a broad principle appears directed at the unwillingness of at least some state courts to police a practice that had the potential to promote inefficient land use decisions. ${ }^{198}$ But the rough-proportionality rule applies only in a narrow set of casesthose in which planners have demanded exactions as conditions for permit approval. ${ }^{199}$ Nollan and Dolan are designed to have little impact beyond the exaction context.

195. Id.

196. Id at $391,390-91$ (detailing states that require municipalities to show a reasonable relationship between the required dedication and the impact of propesed development and concluding that this test has been "adopted by a majority of the state courts").

197. Id. at $389 \& \mathrm{n} .7$ (listing courts requiring that an exaction be directly proportional to the impact created).

198. In addition to the Oregon decision reversed in Dolan, the Court singled out decisions from Montana and New York as applying a standard "too lax to adequately protect petitioner's right to just compensation if her property is taken for a public purpose." Id. at 389.

Justice Scalia's opinion in Nollan identified the inefficiency associated with the unregulated use of exactions:

One would expect that a regime in which this kind of leveraging of the police power is

allowed would produce stringent land-use regulation which the State then waives to accomplish other purposes, leading to lesser realization of the land-use goals purportedly sought to be served than would result from more lenient (but nontradeable) development restrictions.

Nollan, 483 U.S. at 837 n.5. For further discussion of the potential for exactions to create rentseeking opportunities, see Stewart E. Sterk, Nollan, Henry George, and Exactions, 88 COLUM. L. REV. 1731, 1744-47 (1988).

Vicki Been has argued that markets, rather than judicial review, may operate as an effective constraint on municipal use of exactions to extract rents. Vicki Been, "Exit" as a Constraint on Land Use Exactions: Rethinking the Unconstitutional Conditions Doctrine, 91 COLUM. L. REV. 473 (1991). Markets may be less effective, however, as a constraint on municipalities that have no perfect substitutes. See Stewart E. Sterk, Competition Among Municipalities as a Constraint on Land Use Exactions, 45 VAND. L. REV. 831, 854-67 (1992).

199. See City of Monterey v. Del Monte Dunes at Monterey, Ltd., 526 U.S. 687, 702-03 (1999) ("[W]e have not extended the rough-proportionality test of Dolan beyond the special context of exactions-land-use decisions conditioning approval of development on the dedication 


\section{Denial of All Beneficial Use}

In Lucas v. South Carolina Coastal Council, the Court articulated a third categorical rule: Where a regulation "denies all economically beneficial or productive use of land,"200 the regulation is a compensable taking unless background principles of property law would prohibit beneficial use of the land. ${ }^{201}$ As with the categorical rules developed in First English and Nollan-Dolan, the Lucas rule is not dependent on state law, although it does build in a potential defense based on state law. Like the other categorical rules, the Lucas rule, once announced, requires little Supreme Court intervention; by its terms, the rule applies only to complete deprivations. ${ }^{202}$ As a result, the rule is likely to intrude minimally into state regulation of land use; few land use regulations (other than the one enacted by the South Carolina Coastal Council) purport to deny all use of land, and the Court appears unlikely to extend the categorical rule beyond that context. ${ }^{203}$

\section{Permanent Physical Occupations}

The oldest of the Court's categorical rules - that permanent physical occupation constitutes a per se taking-is in many ways the most problematic. The rule, first stated in Loretto $v$. Teleprompter Manhattan CATV Corp., ${ }^{204}$ assumes - correctly - that the right to exclude is an important aspect of property in every state. ${ }^{205}$ In that sense, the permanentphysical-occupation rule depends on state law in a trivial way; the rule depends on state law in an area in which state law is uniform. But how

of property to public use. .. It was not designed to address, and is not readily applicable to, the much different questions arising where... the landowner's challenge is based not on excessive exactions but on denial of development.").

200. 505 U.S. 1003,1015 (1992).

201. Id. at 1029-31.

202. See Tahoe-Sierra Pres. Council v. Tahoe Reg'l Planning Agency, 535 U.S. 302, 330 (2002). The Court there discussed its prior opinion in Lucas as follows:

The emphasis on the word "no" in the text of the opinion was, in effect, reiterated in a footnote explaining that the categorical rule would not apply if the diminution in value were $95 \%$ instead of $100 \%$. Anything less than a "complete elimination of value," or a "total loss," the Court acknowledged, would require the kind of analysis applied in Penn Central.

Id. (citation and footnote omitted).

203. See id.

204. 458 U.S. 419,441 (1982) ("We affirm the traditional rule that a permanent physical occupation of property is a taking.").

205. See Merrill, supra note 92 , at $972,970-72$ ("[T]he right to exclude captures the central features of common-law property that make it such a valuable social institution."). Thus, Justice Marshall's opinion emphasized that "[ $t]$ he power to exclude has traditionally been considered one of the most treasured strands in an owner's bundle of property rights." Loretto, 458 U.S. at 435. 
absolute the right to exclude might be varies significantly among the states; in many, including New York (where Loretto arose), landowners (particularly residential landlords) must bear significant restrictions on the right. $^{206}$ The per se rule adopted in Loretto, then, is to some extent inconsistent with the state law foundations of takings doctrine.

Nevertheless, the Loretto rule shares other attributes with the Court's more recent categorical rules. First, the rule requires little further Supreme Court elaboration. The Court has made it clear that the rule is a narrow one: A statute or ordinance requiring a landlord to accept successor tenants at regulated rents does not constitute a permanent physical occupation by the government, at least so long as the initial tenant's occupation was based on an agreement with the landlord. ${ }^{207}$ Issues remain about the Loretto rule's application to interests in personal property, particularly money. But the Court's most recent takings opinion, Brown v. Legal Foundation of Washington, ${ }^{208}$ appears to resolve many of them by suggesting that the Loretto rule does apply to physical takings of money. ${ }^{209}$ Second, the Loretto rule intrudes only minimally into the power of states and

206. See Rent Stabilization Ass'n v. Higgins, 630 N.E.2d 626 (N.Y. 1993) (upholding, against a takings challenge, a regulation enlarging the class of family members entitled to succeed to the right to occupy a rent-regulated apartment after the death or departure of the original tenant and cataloging the long history of succession rights, which limit the landlord's right to exclude tenants the landlord does not want); N.Y. COMP. CODES R. \& REGS. tit. 9, § 2502.5(b) (2003) (giving a tenant the right to a renewal lease at the expiration of the lease to an apartment subject to rent stabilization regulations).

207. Thus, in Yee v. City of Escondido, 503 U.S. 519 (1992), the owner of a mobile home park challenged a rent control ordinance enacted against the background of a California statute that prevented park owners from terminating or refusing to renew leases for mobile home "pads" and prevented park owners from requiring removal of a mobile home upon sale of the home. The U.S. Supreme Court upheld the ordinance, emphasizing that the park owners had "voluntarily rented their land to mobile home owners." Id. at 527. The Court also noted that the California statute left park owners with an out: They could evict tenants if they converted the land to use for purposes other than a mobile home park. Id. at 528 . The Court did not rely heavily on this last point, because in Loretto, too, the landlord could have avoided that statutory requirement by ceasing to rent the building to tenants. Id. at 531 .

208. 538 U.S. 216 (2003).

209. In Brown, the Court faced a challenge to Washington's use of interest on lawyers' trust accounts (IOLTA) to pay for legal services for the needy. The Court had previously held, in Phillips v. Washington Legal Foundation, that interest income generated by IOLTA funds constituted "private property" of the owner of the principal. 524 U.S. 156, 172 (1998). In Brown, the Court rejected the takings challenge on the ground that the beneficial owner of the principal would have been entitled to no money in the absence of the Washington IOLTA regulation, because the regulation only permitted deposit into an IOLTA account when deposit into a separate account would generate no interest. 538 U.S. at 237-40. As a result, the Court held that even if the IOLTA regulation worked a taking, just compensation would be zero. In the course of its opinion, however, the Court said that if the interest in the accounts is the private property of the owner of the principal (implictly questioning the Court's earlier holding in Phillips), "the transfer of the interest to the Foundation here seems more akin to the occupation of a small amount of rooftop space in Loretto." Id. at 235. As a result, the Court concluded that "a per se approach is more consistent with the reasoning in our Phillips opinion than Penn Central's ad hoc analysis." Id. 
municipalities to regulate land, because regulation rarely takes the form of a physical occupation. ${ }^{210}$

\section{Impact of Land Transfer on Right To Raise Takings Claims}

Palazzolo v. Rhode Island ${ }^{211}$ introduced a fifth categorical rule to the Supreme Court's litany, although the content of the rule remains subject to some doubt. The Rhode Island Supreme Court had dismissed a landowner's takings challenge to wetlands regulations, holding the challenge barred because the landowner had acquired title with notice of the regulations. ${ }^{212}$ The U.S. Supreme Court reversed in an opinion by Justice Kennedy that appeared to suggest that a state may not use acquisition with notice as a basis for barring a landowner's takings claim. ${ }^{213}$ Although five Justices joined the opinion, two wrote concurring opinions offering critically different interpretations of Justice Kennedy's opinion for the Court. Justice Scalia read the opinion to completely tar any consideration of changes in ownership. ${ }^{214}$ Justice O'Connor, by contrast, read the opinion to hold only that a state may not adopt a per se rule barring claims by landowners with notice; whether a landowner acquires land with notice of restrictive regulations could remain a relevant factor in evaluating the claim. ${ }^{215}$

210. The Court in Loretto characterized its holding as "very narrow." 458 U.S. at 441. Moreover, the Court noted that its per se rule would not apply to regulation of landlord-tenant relationships "[s]o long as these regulations do not require the landlord to suffer the physical occupation of a portion of his building by a third party." Id. at 440 . Indeed, the Court stressed that the per se rule it adopted was designed in part to avoid "otherwise difficult line-drawing problems," $i d$. at 436, and that "whether a permanent physical occupation has occurred presents relatively few problems of proof," $i d$. at 437 . See also Tahoe-Sierra Pres. Council v. Tahoe Reg'l Planning Agency, 535 U.S. 302, 324 (2002) ("[P]hysical appropriations are relatively rare, easily identified, and usually represent a greater affront to individual property rights.").

211. 533 U.S. 606 (2001).

212. Palazzolo v. State ex rel. Tavares, 746 A.2d 707, 716 (R.I. 2000), aff'd in part and rev'd in part sub nom. Palazzolo v. Rhode Island, 533 U.S. 606 (2001).

213. Justice Kennedy wrote that "[t]he State's rule would work a critical alteration to the nature of property, as the newly regulated landowner is stripped of the ability to transfer the interest which was possessed prior to the regulation. The State may not by this means secure a windfall for itself." Palazzolo, 533 U.S. at 627.

On the other hand, some of Justice Kennedy's statements were more ambiguous. Thus, he wrote that "[a] blanket rule that purchasers with notice have no compensation right when a claim becomes ripe is too blunt an instrument to accord with the duty to compensate for what is taken." $I d$. at 628 . That statement, for instance, might suggest that a rule that was not a blanket rule might survive constitutional scrutiny, in other words, that the state could take notice into effect, but not make it an absolute bar-the position advocated by Justice O'Connor, id. at 632-36 (O'Connor, J., concurring).

214. Id. at 637 (Scalia, J., concurring) ("In my view, the fact that a restriction existed at the time the purchaser took title... should have no bearing upon the determination of whether the restriction is so substantial as to constitute a taking.").

215. Id. at 632-36 (O'Connor, J., concurring). 
Because only four Justices appear to subscribe to Justice Scalia's broader reading of Justice Kennedy's opinion, its status remains uncertain.

Both Justice O'Connor's narrow rule and the broader one set forth by Justice Scalia operate independently of state law; both rules limit (in different ways) a state's freedom to consider the date of a landowner's acquisition in evaluating the landowner's takings claim. Confusion over the Court's holding may lead to future decisions. But if the Court were definitively to adopt either Justice O'Connor's position or Justice Scalia's, the Court could leave administration to the states; neither position would admit of much ambiguity in interpretation. In addition, neither rule would likely have much effect on the scope of land use regulation; when regulators impose restrictions, they do not know whether or when current owners will transfer their interests. As a result, either version of the Palazzolo rule would have only a marginal impact on state control of the land use process.

\section{Balancing}

When the Supreme Court has agreed to hear takings claims, it has resolved those claims in one of three ways. First, the Court has declined to reach the merits, finding the claims unripe. Second, as the last Section demonstrated, the Court has developed categorical rules to cover some of those cases. In the third category of cases--the subject of this Section-the Court has reached the merits and has applied what it has come to call a "Penn Central analysis,", a balancing test that focuses on "a complex of factors including the regulation's economic effect on the landowner, the extent to which the regulation interferes with reasonable investment-backed expectations, and the character of the government action."217

In practice, however, once the Court applies the balancing test to a state or local regulation, the result is inevitable: The regulation is sustained. ${ }^{218}$ This result, however, is more the product of federalism concerns than of

216. Tahoe-Sierra Pres. Council v. Tahoe Reg'l Planning Agency, 535 U.S. 302, 334 (2002).

217. Palazzolo, 533 U.S. at 617 (majority opinion).

218. See David F. Coursen, The Takings Jurisprudence of the Court of Federal Claims and the Federal Circuit, 29 ENVTL. L. 821, 823 n.12 (1999) ("The Supreme Court has never found a taking of land where it has applied the Penn Central balancing analysis."). Coursen then goes on to distinguish Hodel v. Irving, 481 U.S. 704 (1987), even though the Hodel Court invokes Penn Central's balancing test to support its holding that a congressional statute effected a taking. Coursen, supra, at $823 \mathrm{n} .12$; see also Vicki Been \& Joel C. Beauvais, The Global Fifth Amendment? NAFTA's Investment Protections and the Misguided Quest for an International "Regulatory Takings" Doctrine, 78 N.Y.U. L. REV. 30, 62 (2003) (noting that U.S. courts seldom find regulatory takings under the Penn Central analysis); Basil H. Mattingly, Forum over Substance: The Empty Ritual of Balancing in Regulatory Takings Jurisprudence, 36 WILLAMETTE L. REV. 695, 699 (2000) (analyzing a sample of federal takings cases that suggest a strong presumption in favor of the government). 
hostility to property rights. The Supreme Court has never agreed to review a decision by a state supreme court (or a federal court of appeals) in which that court applied the Penn Central balancing test to strike down a state or local regulation. If a state court has decided that state or local officials have been insufficiently protective of state-created rights, there is little reason for the Supreme Court to invoke the Federal Constitution to interfere with that decision. Instead, the Court has reviewed only cases in which the court below has rejected a challenge to a state or local enactment. In these cases, applying the Penn Central analysis to sustain the regulation-or remanding for a Penn Central analysis by the court below-effectively defers to the decision made by the lower court, ${ }^{219}$ which, in light of the Court's ripeness doctrine, is almost certain to be a state court. ${ }^{220}$

The Penn Central balancing test is not, however, entirely toothless. The Court has applied the test to invalidate federal - but not state-statutes. When federal statutes are involved, uniformity becomes a more important value; a congressional statute should not be enforceable in some states but not others. Moreover, only the Supreme Court can assure uniform treatment of the statute. Finally, in the most significant of these cases-Hodel $v$. Irving - the property right affected by the congressional enactment was itself the product of federal law. ${ }^{22 !}$

The juxtaposition of the Court's treatment of state and federal enactments supports the thesis that takings doctrine has largely been shaped by federalism concerns. ${ }^{222}$ When takings claims involve assertions that depend in large measure on state law, the Court generally leaves policing to the state courts; only when the takings issues can be divorced from state law does the Court typically intervene.

\section{State and Local Enactments}

In Penn Central, the Supreme Court faced a takings challenge by the owner of Grand Central Terminal. ${ }^{223}$ Acting pursuant to the city's Landmarks Preservation Law, the landmarks commission designated the terminal as a landmark and then denied the landowner permission to build an office tower atop the terminal. The landowner brought an action contending that application of the Landmarks Preservation Law to the

219. See infra Subsection III.C.1.

220. See supra Section III.A.

221. 481 U.S. 704.

222. In this respect, the Court's recent takings jurisprudence is a counterexample to Richard Fallon's conclusion that "[w]hen federalism and substantive conservatism come into conflict, substantive conservatism frequently dominates." Richard H. Fallon, Jr., The "Conservative" Paths of the Rehnquist Court's Federalism Decisions, 69 U. CHI. L. REV. 429, 434 (2002).

223. 438 U.S. 104 (1978). 
terminal property had worked an unconstitutional taking. The New York Court of Appeals rejected the takings challenge. ${ }^{224}$ In affirming, the Supreme Court, in an opinion by Justice Brennan, attempted to synthesize the Court's takings jurisprudence. The opinion set forth a number of factors relevant in takings cases- "[ $t]$ he economic impact of the regulation on the claimant," "the extent to which the regulation interferes with distinct investment-backed expectations," and "the character of the governmental action"225_but conceded that the Court's doctrine had been marked by "essentially ad hoc, factual inquiries," and that the Court "has been unable to develop any 'set formula' for determining" when compensation is due. ${ }^{226}$

The Court has repeatedly cited Penn Central for its conclusion that takings doctrine is characterized more by ad hoc inquiries than by any set formula. ${ }^{227}$ But, in fact, takings law since Penn Central has generated one set formula: Whenever the Court conducts a Penn Central analysis of a state or local regulation, the regulation stands. ${ }^{228}$

Sometimes, the Court has reached this result by expressly acknowledging state authority to define property in the first instance. Thus, in PruneYard Shopping Center v. Robins, the Court sustained against a takings challenge a state constitutional provision newly construed to require a shopping center owner to permit solicitation of support for political positions. ${ }^{229}$ In affirming the California Supreme Court, the Court emphasized that as a general proposition the states-not the federal government-enjoy the "residual authority" to define property rights. ${ }^{230}$ Similarly, in Keystone Bituminous Coal Ass'n v. DeBenedictis, the Court upheld a Pennsylvania subsidence statute after considering seriously the argument that, although comparable legislation might be constitutional in

224. Penn Cent. Transp. Co. v. City of New York, 366 N.E.2d 1271 (N.Y. 1977), aff'd, 438 U.S. 104 (1978).

225. Penn Cent., 438 U.S. at 124

226. Id.

227. See, e.g., Tahoe-Sierra Pres. Council v. Tahoe Reg'l Planning Agency, 535 U.S. 302, 326 (2002); Palazzolo v. Rhode Island, 533 U.S. 606, 633 (2001) (O'Connor, J., concurring); Lucas v. S.C. Coastal Council, 505 U.S. 1003, 1015 (1992).

228. Since Penn Central was decided, the Court has invalidated state or local statutes as takings in only one case (other than those in which the Court applied a categorical rule). That case, Webb's Fabulous Pharmacies v. Beckwith, 449 U.S. 155 (1980), involved not a regulation of land but a state statute entitling the state to impose a clerk's fee for money deposited with a court to protect the depositor from creditors, and also to retain the interest on the money deposited. The Court treated the case not as a regulatory case, but as one in which the government had physically appropriated money as in United States v. Causby, 328 U.S. 256 (1946), where the government physically appropriated the use of airspace for military aircraft. Webb's, 449 U.S. at 163-64. In other words, had Webb's been decided after Loretto, the Court probably would have invoked the permanent-physical-occupation per se rule and held that the state had permanently occupied the depositor's money.

229. 447 U.S. 74 (1980).

230. Id. at 84 . 
other states, the challenged statute was unconstitutional because Pennsylvania law is unique in treating the support estate as a separate interest in land. ${ }^{231}$ The Court rejected the argument only after deferring to the conclusion reached by the federal court of appeals, "which is more familiar with Pennsylvania law than we are," that in practice, "the support estate is always owned by either the owner of the surface or the owner of the minerals." 232 And in Tahoe-Sierra Preservation Council v. Tahoe Regional Planning Agency, the Court, in affirming a Ninth Circuit decision rejecting a challenge by landowners to a development moratorium, noted that the landowners had purchased "amidst a heavily regulated zoning scheme."233

In other cases, the Court has been silent about the state role in defining property rights, but has nevertheless upheld a decision of the state supreme court or remanded to the state supreme court for final resolution of the takings claim. Thus, in Agins $v$. City of Tiburon, the Court upheld a California Supreme Court determination that rejected the landowner's claim that a zoning ordinance had effected a taking when it limited the landowner to construction of five single-family homes on a five-acre tract. $^{234}$ And in Palazzolo v. Rhode Island, the Court remanded the landowner's takings claim to the state supreme court to conduct a Penn Central analysis informed by the Court's holding that purchase with notice of the challenged restrictions could not serve as a bar to a landowner's takings claim. ${ }^{235}$ The Court's consistent refusal in these cases to invalidate state and local enactments suggests that the Penn Central balancing test is little more than an exhortation to state courts to take takings seriously. The Court has demonstrated no inclination to overturn applications of the balancing test by either state courts or lower federal courts.

\section{Federal Enactments}

The Supreme Court's takings jurisprudence extends beyond challenges to state and local regulation, however. The Court has also entertained takings challenges to federal statutes. And a number of these challenges have raised questions not about the application of categorical rules, but instead about the application of the Penn Central analysis. If the Court were routinely to reject these challenges, as it rejects similar challenges to

231. 480 U.S. 470,500 (1987).

232. Id.

233. 535 U.S. 302,313 n.5 (2002). The Court also emphasized that the states-and particularly state legislatures-should and do play a role in policing abusive development moratoria. Id. at $341-42$ \& n.37.

234. 447 U.S. $255(1980)$.

235. 533 U.S. $606(2001)$. 
state and local enactments, one might simply conclude that the Court is generally unsympathetic to takings challenges. In fact, however, the Court has--twice-applied a Penn Central analysis to invalidate a federal statute. Taken in combination with the Court's treatment of state and local regulations, these cases suggest not hostility to takings claims, but instead recognition that the policing of state and local regulations is best left to the state and lower federal courts.

The Court's first application of Penn Central balancing to invalidate a federal statute came in Hodel $v$. Irving. ${ }^{236}$ Responding to concerns about fractionated ownership of Indian lands, Congress enacted a statute providing that an undivided fractional interest in a tract of tribal land would not pass by intestacy or devise, but would instead escheat to the tribe if the interest represented two percent or less of the tract's acreage and earned its owner less than $\$ 100$ in the year before it was due to escheat. ${ }^{237}$ When victims of the escheat provision challenged its constitutionality, the Court concluded that the statute worked a taking, despite the inability of the victims to point to any "specific investment-backed expectations." 238 In applying the balancing test derived from Penn Central, the Court emphasized the importance of the right to pass on one's property at death. ${ }^{239}$

More recently, in Eastern Enterprises v. Apfel, the Court invalidated a federal statute imposing on companies that had employed workers in the coal industry an obligation to fund retiree health benefits, even though those companies had long since exited the coal industry. ${ }^{240}$ In Eastern Enterprises, the Court deferred neither to Congress nor to the court of appeals; the First Circuit had sustained the statute against constitutional attack. $^{241}$ Justice O'Connor's plurality opinion was founded on the Takings Clause, ${ }^{242}$ although Justice Kennedy, the fifth vote for the Court's result, relied on the Due Process Clause instead. ${ }^{243}$ Justice O'Connor's analysis used a balancing test based on the factors first developed in Penn Central. ${ }^{244}$

236. 481 U.S. 704 (1987).

237. Id. at 709 .

238. Id. at 715 .

239. Id. at 716. The Court's analysis and conclusion followed its quotation of the "[no] set formula" and "ad hoc, factual inquiries" language from Penn Central. Id. at 714 (internal quotation marks omitted).

240. 524 U.S. 498 (1998).

241. E. Enters. v. Chater, 110 F.3d 150 (1st Cir. 1997), rev'd sub nom. E. Enters. v. Apfel, 524 U.S. 498 (1998).

242. E. Enters., 524 U.S. at 522-29.

243. Id. at 539 (Kennedy, J., concurring in the judgment and dissenting in part).

244. Justice O'Connor's plurality opinion discussed "[t]he economic impact of the regulation," id. at 500 (plurality opinion), the coal company's "investment-backed expectations," id. at 532, and "the nature of the governmental action," id. at 537. 
In neither Hodel nor Eastern .Enterprises did the property "taken" depend on state law. In Hodel, the subject lands were initially allocated to individual Indians by federal statute. ${ }^{245}$ In Eastern Enterprises, the property "taken" was fungible money rather than any specific property interest-an issue that prevented Justice O'Connor from obtaining a majority for her opinion. ${ }^{246}$ But in any event, the background law that led Congress to impose a financial obligation on Eastern Enterprises was heavily federal; many of the earlier informal understandings arose from agreements negotiated pursuant to federal labor laws, ${ }^{247}$ while some of the later understandings were based on agreements designed to assure compliance with ERISA. ${ }^{248}$

Because neither the offending statutes nor the legal background was a product of state law, the Court in Hodel and Eastern Enterprises could decide the takings questions without becoming enmeshed in state law intricacies. Moreover, the predominance of federal issues imbued the Court's opinions with greater guidance value, both for potentially disputing parties and for the federal courts. Invalidation of the Indian Land Consolidation Act had an impact on all Indian lands, not merely on those in a single state. When the Court relieved Eastern Enterprises of liability under the Coal Act, the decision had an immediate impact-both on other firms that had left the coal industry and on Congress-in setting the boundaries for similar legislation. Finally, only the Court could have provided this guidance; these were matters that could have provoked division among the courts of appeals.

William Fischel has argued that in the takings area, courts should "largely avert their eyes from the regulatory excesses of Congress" because pluralist politics will generally assure adequate protection for property rights. ${ }^{249}$ Hodel and Eastern Enterprises indicate that the Court has not embraced that view. Instead, when these two cases are considered in conjunction with the Court's failure to apply the Penn Central analysis to invalidate state and local legislation, they suggest that federalism concerns lie at the heart of the Supreme Court's takings jurisprudence. When the property taken and the offending regulation are both the product of state law, the Court will generally leave the takings issue to the state courts.

245. Hodel v. Irving, 481 U.S. 704, 706-07 (1987).

246. E. Enters., 524 U.S. at 540-47 (Kennedy, J., concurring in the judgment and dissenting in part); id. at 554-57 (Breyer, J., dissenting); see also Merrill, supra note 92, at 900-07.

247. E. Enters., 524 U.S. at 504-09 (plurality opinion) (detailing agreements between the United Mine Workers of America and coal operators).

248. Id. at 509 (discussing the 1974 agreement, designed to comply with ERISA, which was the first agreement "to expressly reference health benefits for retirees").

249. FISCHEL, supra note 63, at 140. 


\section{THE STATES AS GUARDIANS OF PROPERTY RIGHTS}

The preceding two Parts have demonstrated, first, that as a matter of theory, the states are better suited to police overzealous land use regulation than is the Supreme Court and, second, that the Supreme Court has in practice left much of the policing to the states. What remains is to examine whether the states have been, or can be, effective in protecting property rights against excessive and unanticipated change.

Measuring the effectiveness of states in protecting property rights is, by necessity, plagued by imprecision. Property rights are the product of positive state law. If a state has habitually been hostile to broadly defined property rights, the concerns that lie behind the Takings Clause provide little reason for the legislature or courts to intervene when a municipality takes actions that landowners have been conditioned to anticipate. A state's failure to act to protect property owners, then, need not be inconsistent with constitutional norms.

Nevertheless, it is worth examining the ways in which states have responded to local regulation of property, both by legislation and by judicial action.

\section{A. Legislation}

\section{Property Rights Legislation}

During the 1990s, many state legislatures, prompted by property rights advocates, enacted statutes explicitly designed to protect property owners against confiscatory regulation. ${ }^{250}$ The most common form of legislation requires preparation of a "takings impact assessment" before a government action limiting or otherwise affecting the use of real property. ${ }^{251}$ These statutes are procedural in nature; they are designed to assure that some government agency has assessed the impact of potentially confiscatory

250. See Mark W. Cordes, Leapfrogging the Constitution: The Rise of State Takings Legislation, 24 ECOLOGY L.Q. 187, 204-20 (1997); F. Patrick Hubbard, "Takings Reform" and the Process of State Legislative Change in the Context of a "National Movement," 50 S.C. L. REV. 93, 109-20 (1998); David A. Thomas, The Illusory Restraints and Empty Promises of New Property Protection Laws, 28 URB. LAW. 223 (1996); Carl P. Marcellino, Note, The Evolution of State Takings Legislation and the Proposals Considered During the 1997.98 Legislative Session, 2 N.Y.U. J. LEGIS. \& PUB. POL'Y 143 (1998-1999).

251. On March 15, 1988, President Reagan issued Executive Order 12,630, which required federal agencies to conduct a takings impact assessment. Exec. Order No. 12,630, 53 Fed. Reg. 8859 (Mar. 18, 1988). Although the Executive Order proved ineffective, it served as the pattern for state assessment statutes. Lynda J. Oswald, Property Rights Legislation and the Police Power, 37 AM. BUS. L.J. 527, 541-42 (2000).

Examples of state assessment statutes include DEL. CODE ANN. tit. 29, $\S 605$ (2003); IDAHO CODE $§ 67-8003$ (Michie Supp. 2004); and IND. CODE $\S 4-22-2-32$ (2004). 
legislation but do not necessarily require a particular result or afford any judicial remedy to landowners affected by government action. ${ }^{252}$ The statutes vary considerably in scope: Some apply only to actions by state agencies, ${ }^{253}$ while others include actions taken by local governments. ${ }^{254}$ Assessment statutes generally do not subject government action to new substantive legal standards. Instead, they serve as direction to state officials to enforce existing state and federal constitutional limitations. Indeed, the statutes often define takings by reference to the Fifth and Fourteenth Amendments of the Federal Constitution. ${ }^{255}$

Legislation in several states goes beyond a mere assessment requirement and invalidates regulations that would, without compensation, reduce the value of landowners' land by more than a specified percentage. ${ }^{256}$ The Texas statute is illustrative, defining a taking to include both deprivations of rights protected by the state and federal constitutions and government actions that are "the producing cause of a reduction of at least 25 percent in the market value of the affected private real property." 257 If the landowner can establish that governmental action constitutes a taking within the meaning of the statute, the landowner is entitled to invalidation of the action. ${ }^{258}$

A third set of states has enacted statutes designed to promote negotiation between landowners and local governments when regulation threatens landowners' interests. ${ }^{259}$ The Florida statute, for instance, permits a landowner to bring suit against a governmental entity that has imposed an "inordinate burden" on real property ${ }^{260}$ and provides expressly that the statutory cause of action extends to actions that "may not rise to the level of

252. In this respect, the statutes resemble section $102(2)(C)$ of the National Environmental Policy Act of 1969, 42 U.S.C $\S 4332$ (2)(C) (2000), and its state counterparts, which require preparation of environmental impact statements before government may take action with environmental significance, see, e.g., N.Y. ENVTL. CONSERV. LAW § 8-0109 (McKinney 1997).

253. See, e.g., DEL. CODE ANN. tit. 29, § 605; KAN. STAT. ANN. $\S \S 77-703,-706$ (1997); MONT. CODE ANN. $\S \S 2-10-101$ to -105 (2003).

254. See, e.g., IDAHO CODE $§ 67-8003$.

255. See, e.g., DEL. CODE ANN. tit. $29, \S 605$ (c) ("The term 'taking of private property' as used under this section shall mean an activity wherein private property is taken such that compensation to the owner of that property is required by the Fifth and Fourteenth Amendments to the Constitution of the United States or any other similar or applicable law of this State."); see also MO. REV. STAT. § 536.017 (2003); MONT. CODE ANN. § 2-10-104(2); N.D. CENT. CODE $\S 28-32-09$ (3) (Supp. 2003).

256. See LA. REV. STAT. ANN. §§ 3:3601 -:3624 (West 2003); MISS. CODE ANN. §§ 49-33-1 to -17 (1999); TEX. GOV'T CODE ANN. $\$ \S 2007.001-.045$ (Vernon 2000).

257. TEX. GOV'T CODE ANN. $\S 2007.002(5)(B)(i i)$.

258. Id. $\S \S 2007.023-.024$. The government can then elect to pay damages to avoid invalidation of the action. Id. $\$ 2007.024$.

259. See, e.g., Fla. STAT. ch. 70.001 (2004); ME. ReV. Stat. ANN. tit. 5, § 3341 (West 2002).

260. FLA. STAT. ch. $70.001(6)$ (a). 
a taking under the State Constitution or the United States Constitution."261 The statute, however, requires the landowner to present the claim in writing to the government entity 180 days before filing the action and then gives the entity 180 days to make a settlement offer. ${ }^{262}$

Both the wisdom and the ultimate effectiveness of these statutes remain the subject of debate. ${ }^{263}$ For present purposes, however, the statutes are important as a demonstration that state legislatures are a forum in which landowners and developers enjoy a significant voice.

\section{Statutory Limits on Moratoria}

In recent decades, many municipalities have imposed development moratoria to prevent construction that would have been permitted under existing regulations. Sometimes, the moratoria have been designed to prevent the overloading of public facilities not yet equipped to service new development; at other times, they have been designed to permit the municipality to redraft its zoning ordinance to preclude likely new development. ${ }^{264}$ Although moratoria purport to be temporary, they often endure for years, provoking takings challenges like the one the Supreme Court ultimately rejected in Tahoe-Sierra Preservation Council v. Tahoe Regional Planning Agency. ${ }^{265}$ In refusing to hold that the Federal Constitution imposes an outside limit on the duration of development moratoria, the Court indicated that crafting limits on moratoria was "a suitable task for state legislatures." 266 The Court listed eleven state statutes that had imposed specific time limits, ${ }^{267}$ but the Court's list was not comprehensive. Several other states have imposed time limits on development moratoria, although many permit extensions in certain circumstances. ${ }^{268}$ Once again, these statutes indicate that state legislatures are prepared to limit regulatory practices that threaten landowner interests.

261. Id. ch. $70.001(9)$.

262. Id. ch. 70.001(4).

263. Compare Nancie G. Marzulla, State Private Property Rights Initiatives as a Response to "Environmental Takings," 46 S.C. L. REV. 613 (1995) (supporting state statutes), with John D. Echeverria, The Politics of Property Rights, 50 OKLA. L. REV. 351 (1997) (expressing concern about the impact on environmental issues).

264. See ELLICKSON \& BEEN, supra note 192, at 970.

265. 535 U.S. 302 (2002). In Tahoe-Sierra, the Court dealt with two successive moratoria that prohibited virtually all development for a thirty-two-month period. $I d$. at 306 . The dissenting Justices, however, characterized the ban as lasting for almost six years. Id. at 343-46 (Rehnquist, C.J., dissenting).

266. Id. at 342 (majority opinion).

267. Id. at 342 n.37.

268. See ARIZ. REV. STAT. \& 9-463.06(E) (2004) (120-day limit, subject to extensions); ME. REV. STAT. ANN. tit. 30-A, $\S 4356$ (West 1996) (180-day period, subject to extensions); N.J. ST.AT. ANN. $§ 40: 55 \mathrm{D}-90$ (West 1991) (permitting moratoria only to protect against imminent 


\section{Other Legislation}

The enactment of property rights legislation, together with the imposition of statutory limits on development moratoria, suggest that the political power developers enjoy in state legislatures provides them with significant protection against potentially abusive practices by local governments. The evidence, however, is not limited to these examples. Many states have enacted statutes that limit municipal power to prevent development through inaction. These statutes deem a development application to be approved if the relevant municipal body does not act on it within the statutory time frame. ${ }^{269}$ In addition, state legislation designed to implement the Supreme Court's decisions in Nollan and Dolan places limits on the ability of local governments to impose "impact fees" on new development. ${ }^{270}$ And even more modest statutes-like those defining the bases on which local boards may grant or deny variances-act to constrain local government power to thwart new development. ${ }^{271}$ Even if these statutes do not deal with potential takings, they suggest that state legislatures, as institutions, have promise as a bulwark against local regulation that appears inefficient or abusive. Landowners will not always win in the state legislatures, but their interests will not be ignored.

danger to health, with a six-month time period); TEX. LOC. GOV'T CODE ANN. $\$ 212.136$ (Vernon Supp. 2004-2005) (120-day period, subject to extensions).

269. See, e.g., CONN. GEN. STAT. § 8-26 (Supp. 2004) ("The failure of the commission to act $\ldots$ shall be considered as an approval ....”); N.Y. VILLAGE LAW $\S 7-728(8)$ (McKinney Supp. 2004) ("In the event a planning board fails to take action on a preliminary plat or a final plat within the time prescribed therefor ... such preliminary or final plat shall be deemed granted approval.").

In Tall Trees Construction Corp. v. Zoning Board of Appeals, 761 N.E.2d 565 (N.Y. 2001), the New York Court of Appeals dealt with another mechanism local boards sometimes use to delay land use approvals: repeated tie votes, often caused by abstentions of one or more board members. The court construed New York statutes to require that a tie vote be treated as a denial of an application, rather than a nonaction, thus triggering the availability of judicial review.

270. Some statutes explicitly prohibit use of impact fees for particular purposes. See, e.g., COLO. REV. STAT. § 22-54-102 (2002) (prohibiting impact fees for school financing). Other states limit discretion in assessing fees even as they authorize use of impact fees. See, e.g., 605 ILL. COMP. STAT. $\S \S 5 / 5-901$ to -905 (2004) (authorizing road improvement fees); TEX. LOC. GOV'T CODE ANN. $\S \S 395.011-.080$ (Vernon 2002) (permitting use of fees only for improvements with a life expectancy of at least three years).

271. Thus, in 1991 the New York legislature enacted a statute providing explicit standards by which local zoning boards were to evaluate applications for area variances. These standards replaced a regime in which local governments prohibited the grant of a variance, however trivial, when the landowner failed to demonstrate "practical difficulties" or "undue hardship." The new statute preempted local variance standards and effectively precluded local governments from routinely rejecting variance applications. See Cohen v. Bd. of Appeals, 795 N.E.2d 619 (N.Y. 2003) (holding that the new statute, N.Y. VILLAGE LAW \& 7-712-b(3)(b) (McKinney 2004), preempted local variance standards). 


\section{B. State Courts}

Legislation typically works prospectively. Because legislatures are not in a position to anticipate every potential local government abuse, state courts also play a role in policing local government action. Moreover, judicial review can provide a useful check on those occasions when state legislatures are themselves captured by interest groups.

State court limits on local land use regulation need not emanate from the Federal Constitution. Instead, state courts often invoke state statutes and state constitutional provisions to invalidate regulations promulgated by local and even state governments. Even when landowners advance, and state courts consider, challenges based on federal takings jurisprudence, nothing in the United States Supreme Court's takings jurisprudence precludes active state court intervention. First, because every state has a constitutional provision prohibiting uncompensated taking (and sometimes damaging) of property, state courts can invoke an independent source of authority for providing landowners more protection than the Federal Constitution would require. ${ }^{272}$ Second, the Court's Penn Central test is best viewed not as a finely calibrated analysis of constitutional limits, but as a delegation of authority to the state courts.

This Section offers a broad overview of the doctrinal responses state courts have developed toward overzealous land use regulation. The overview does not purport to be comprehensive. Comprehensive treatment of the practices of fifty state courts would be unwieldy, especially because local variations are significant. Moreover, any sampling of cases or states is subject to the inevitable criticism that the samples were chosen to support the author's conclusions.

Against that background, the Section's objectives are modest. First, it explores some of the more common doctrinal strategies (other than invocation of the Takings Clause) that state courts have used to overturn local land use decisions. Second, it turns to explore more systematically the Takings Clause analysis developed in the courts of two states, California and New York. These states were chosen for several reasons. First, of the four largest states, California and New York are the two whose high courts have generally enjoyed the highest esteem. Second, of those four states, California and New York are the two that have not enacted property rights

272. 1 JULIUS L. SACKMAN, NICHOLS ON EMINENT DOMAIN $\S 1.3$ (3d ed. 2004) (noting that all state constitutions other than that of North Carolina include a takings clause). The North Carolina Supreme Court has inferred a prohibition on takings without just compensation from article I, section 19 of its state constitution, which provides that no person shall be "deprived of his . . property, but by the law of the land." Long v. City of Charlotte, 293 S.E.2d 101, 108 n.6 (N.C. 1982) (internal quotation marks omitted). 
legislation. Third, both states have long histories of takings litigation, dating back to a time when each state's high court had held that landowners' claims of unconstitutional regulation could never give rise to money damages. Finally, in light of the renowned hostility of the California courts to landowners' claims, focus on California provides some insulation from the contention that these states were cherry-picked to support the Article's thesis.

\section{Developing State Law Doctrines To Control Local Regulatory Abuse}

Municipalities are creations of the states in which they sit. Their regulatory powers derive entirely from state law. ${ }^{273}$ As a result, state courts have, on many occasions, concluded that locally enacted land use controls were invalid because state law did not explicitly or implicitly authorize the challenged regulations. For instance, the Missouri Supreme Court has held that a township lacked statutory authority to impose setback and bonding requirements on agricultural uses. ${ }^{274}$ And the Supreme Judicial Court of Massachusetts has held that the City of Cambridge lacked statutory authority to impose restrictions on the sale of individual condominium units. ${ }^{275}$

Also common are state court opinions holding that state law preempts local regulation of land use. Sometimes, the preemption involves a relatively straightforward reading of the preempting statute, as in the recent holding by the New York Court of Appeals that state standards for grants of area variances preempt local regulations that would make it easier for municipalities to deny variances. ${ }^{276}$ On other occasions, however, preemption involves an expansive construction of the state statute, as when

273. "Dillon's Rule," derived from an influential nineteenth-century treatise, provides that a municipal corporation possesses, and can exercise, the following powers, and no others: First, those granted in express words; second, those necessarily or fairly implied in, or incident to, the powers expressly granted; third, those essential to the declared objects and purposes of the corporation-not simply convenient, but indispensable. Any fair, reasonable doubt concerning the existence of power is resolved by the courts against the corporation, and the power is denied.

JohN F. Dillon, TREatise ON THE LAW OF MUNiCIPAL CORPORATIONS $\S 55$, at 101-02 (Chicago, J. Cockcroft 1872) (emphasis omitted).

274. Premium Standard Farms v. Lincoln Twp., 946 S.W.2d 234 (Mo. 1997) (invalidating setback and bonding requirements imposed by a town in a transparent attempt to make it financially unfeasible for the landowner to operate a hog farm on the 3000 acres it had purchased for that purpose).

275. Steinbergh v. Rent Control Bd., 546 N.E.2d 169, 172 (Mass. 1989) (relying on the principle that a municipality may exercise only those powers affirmatively granted to it).

276. Cohen, 795 N.E.2d 619. For another example, see Sawyer Environmental Recovery Facilities v. Town of Hampden, 760 A.2d 257 (Me. 2000) (holding that a state environmental statute preempted a local ordinance that would impose more stringent limitations on a landfill). 
the Washington Supreme Court invalidated a city's requirement that thirty percent of a developer's parcel be set aside as open space, holding that the regulation constituted a tax on development in violation of a state statute prohibiting municipalities from imposing any "direct or indirect taxes, fees or charges on the development or subdivision of land."277

Although most preemption decisions turn on state statutes, the New Jersey Supreme Court, in Southern Burlington County NAACP v. Township of Mouni Laurel, invoked the state constitution as a basis for limiting the power of municipalities to engage in fiscal zoning-the practice of excluding uses (particularly multiple-family residences) that would generate more tax burdens than tax revenues. ${ }^{278}$

Even when local land use decisions do not conflict with state statutes or constitutional provisions, most state courts nevertheless scrutinize those decisions to determine whether they are arbitrary and unreasonable or are supported by substantial evidence. Some courts purport to derive authority for this sort of judicial review from constitutional principles, ${ }^{279}$ others are less explicit about the basis for this review. ${ }^{280}$

Each of these state law doctrines operates to constrain municipal land use regulation that might otherwise generate takings claims. Moreover, especially since the Supreme Court decided First English, a number of state

277. Isla Verde Int'l Holdings v. City of Camas, 49 P.3d 867, 875 (Wash. 2002).

278. 336 A.2d 713 (N.J. 1975). When the NAACP brought an action to challenge fiscal zoning in Mount Laurel, the New Jersey Supreme Court held that each municipality had a constitutional obligation to bear its fair share of the regional burden of providing housing for persons with low and moderate incomes. Id. Later, the court authorized a "builder's remedy" to assure that municipalities met their newly defined state constitutional obligations. S. Burlington County NAACP v. Twp. of Mount Laurel, 456 A.2d 390, 413 (N.J. 1983). Although the Mount Laurel courts' concern was not protection of property rights, the courts indirectly assisted landowners whose property values had been suppressed by restrictive zoning ordinances, though they may have harmed neighbors whose property values declined due to low-income housing nearby.

279. See, e.g., Shemo v. Mayfield Heights, 722 N.E.2d 1018, 1021 (Ohio 2000) (holding that where no taking is alleged, the court need only decide whether an ordinance was arbitrary and unreasonable); $i d$. at 1023, 1023-24 (invalidating as unconstitutional a residential classification in an area where "three-quarter million square feet of retail space" were located in the vicinity of a parcel); In re Appeal of Realen Valley Forge Greenes Assocs., 838 A.2d 718, 728 (Pa. 2003) (citing a prior case for the proposition that an arbitrary ordinance violates substantive due process and invalidating agricultural zoning of a tract immediately adjacent to the world's largest shopping complex); Mission Springs v. City of Spokane, 954 P.2d 250, 259 (Wash. 1998) (" $[A]$ rbitrary administration of the local regulations, which singles out one individual to be treated discriminatorily, amounts to a violation of that individual's substantive due process rights.").

280. See, e.g., Town of Florence v. Sea Lands, Ltd., 759 So. 2d 1221, 1223 (Miss. 2000) (holding that a board decision "must be upheld unless it is arbitrary, capricious, discriminatory, or is illegal, or without a substantial evidentiary basis" (internal quotation marks omitted)); Pheasant Bridge Corp. v. Twp. of Warren, 777 A.2d 334, 339 (N.J. 2001) (holding that a landowner overcomes a strong presumption of validity by demonstrating that an ordinance is arbitrary, capricious, or unreasonable); Turner v. Bd. of County Supervisors, 559 S.E.2d 683, 686 (Va. 2002) (citing other cases for the proposition that a zoning ordinance is valid "so long as it is not unreasonable and arbitrary" (internal quotation marks omitted)). 
courts have developed a clear preference for policing local regulation with state law doctrines rather than the Federal Constitution's Takings Clause. These courts have concluded that by characterizing the local regulation as invalid under state law, they can avoid awarding money damages to the aggrieved landowner-damages that would be available under First English if the regulation were held invalid as an unconstitutional taking. ${ }^{281}$ Put another way, by mandating damage awards, even for temporary takings, the Supreme Court has increased the likelihood that state courts will invoke state law, rather than the Federal Constitution, as the basis for invalidating abusive land use regulations.

\section{State Takings Litigation}

In light of the state law doctrines available to police regulatory abuse, it should not be surprising that state courts reject the overwhelming majority of takings claims. Nevertheless, many state courts have, in recent years, invoked the federal Takings Clause or its state constitutional counterparts to invalidate regulations that do not fall within any of the Supreme Court's per se rules. Moreover, many of the state court decisions to invalidate regulations (as well as many decisions to uphold regulations) rest on peculiarities of state law that make the state courts better suited than the Supreme Court to resolve the disputed issues. This Subsection examines the approach taken by the high courts in California and New York, together with highlights from a number of other states.

\section{a. California}

Because California's hostility to development interests is of such long standing, ${ }^{282}$ the California Supreme Court's more recent rejection of takings claims is reconcilable with the thesis that state courts will provide

281. See, e.g., Landgate, Inc. v. Cal. Coastal Comm'n, 953 P.2d 1188 (Cal. 1998) (holding that the First English rule does not apply when the development prohibition results from error by a governmental agency); Torromeo v. Town of Fremont, 813 A.2d 389, 392 (N.H. 2002) ("Absent a determination that the ordinance is unconstitutional and constitutes a taking, this case presents merely the type of municipal error for which judicial reversal of the erroneous action is the only remedy."); Pheasant Bridge, 777 A.2d at 343 ("A per se compensable taking does not occur as a result of the temporary application of a zoning ordinance that is ultimately declared invalid in a judicial challenge to the municipal zoning authority.").

For criticism and rejection of efforts like these to narrow First English, see Eberle v. Dane County Board of Adjustment, 595 N.W.2d 730, 741-43 (Wis. 1999) (rejecting the California court's approach in Landgate and overruling language from a prior Wisconsin intermediate appellate court opinion taking the same approach).

282. See FISCHEL, supra note 63, at 226-31; Joseph F. DiMento et al., Land Development and Environmental Control in the California Supreme Court: The Deferential, the Preservationist, and the Preservationist-Erratic Eras, 27 UCLA L. REV. 859 (1980). 
adequate protection for property rights. Both local governments and the California courts have been hostile to developer interests for so long that newly enacted measures do little more than actuate the risks that all Californians assume when they acquire land. Because landowners hold weak property interests in the first place, few regulations generate an unconstitutional taking of those interests.

William Fischel has blamed the California Supreme Court's antidevelopment decisions for part of the explosion in California housing prices during the $1970 \mathrm{~s} .{ }^{283}$ It is no accident that California cases were at the center of the resurgence of the U.S. Supreme Court's regulatory takings jurisprudence; a grossly disproportionate number of the Court's takings cases since 1980 have involved takings claims rejected by the California courts. $^{284}$

More recent cases reveal no dramatic change in the California Supreme Court's approach. First, that court typically treats the Takings Clause as a

283. FISCHEL, supra note 63 , at 234-52.

284. Those cases include, in chronological order, PruneYard Shopping Center v. Robins, 447 U.S. 74 (1980) (involving a case in which the California Supreme Court had rejected the takings claim of a shopping center owner who challenged a state constitutional provision permitting distribution of pamphlets); Agins v. City of Tiburon, 447 U.S. 255 (1980) (involving a case in which the California Supreme Court had rejected a claim that a zoning ordinance effected a taking and had indicated that the landowner would not, in any event, be entitled to money damages); San Diego Gas \& Electric Co. v. City of San Diego, 450 U.S. 621 (1981) (involving a case in which the California Court of Appeal had rejected a landowner's money damages claim, concluding that only mandatory or declaratory relief would be available); MacDonald, Sommer \& Frates v. County of Yolo, 477 U.S. 340 (1986) (involving a case in which the California Court of Appeal had rejected a landowner's takings claim arising out of rejection of a subdivision plan); First English Evangelical Lutheran Church v. County of Los Angeles, 482 U.S. 304 (1987) (involving a case in which the California Court of Appeal had held that money damages were not available as a remedy for taking); Nollan v. California Coastal Commission, 483 U.S. 825 (1987) (involving a case in which the California Court of Appeal had rejected a takings claim when a municipality had required the grant of an easement as a predicate to development approval); Pennell v. City of San Jose, 485 U.S. 1 (1988) (involving a case in which the California Supreme Court had rejected a takings challenge to a rent control ordinance); and Yee v. City of Escondido, 503 U.S. 519 (1992) (involving a case in which a California court rejected a takings claim by owners of a mobile home park challenging a rent control ordinance).

In addition, two other cases arose out of Ninth Circuit decisions rejecting landowner takings claims against the Tahoe Regional Planning Agency, a regulatory body created by bi-state compact between California and Nevada. See Tahoe-Sierra Pres. Council v. Tahoe Reg'l Planning Agency, 535 U.S. 302 (2002) (involving a case in which the Ninth Circuit rejected a takings claim arising from a development moratorium); Suitum v. Tahoe Reg'l Planning Agency, 520 U.S. 725 (1997) (involving a case in which the Ninth Circuit held a takings claim unripe).

Finally, in City of Monterey v. Del Monte Dunes at Monterey, Ltd., 526 U.S. 687 (1999), the Supreme Court affirmed a Ninth Circuit decision that in a $\S 1983$ action for deprivation of property, the jury should determine the reasonableness of municipal action.

By contrast, during the same period (since 1980) the Court has reviewed only three takings challenges (Keystone Bituminous Coal Ass' $n$ v. DeBenedictis, 480 U.S. 470 (1987); Loretto v. Teleprompter Manhattan CATV Corp., 458 U.S. 419 (1982); and Webb's Fabulous Pharmacies v. Beckwith, 449 U.S. 155 (1980)) to government actions emanating from the next ten largest states (Texas, New York, Florida, Illinois, Pennsylvania, Ohio, Michigan, New Jersey, Georgia, and North Carolina). 
constraint imposed from above. Although the California Constitution includes broader language than the Federal Constitution-providing that property may be "taken or damaged" for public use only upon payment of just compensation ${ }^{285}$ - the California Supreme Court has largely ignored the difference in constitutional language, construing the federal and state clauses congruently. ${ }^{286}$ Indeed, in one recent case in which the landowner only advanced a claim under the state constitution, the court nevertheless analyzed (and rejected) the claim primarily by examining the U.S. Supreme Court's construction of the Federal Constitution. ${ }^{287}$

Moreover, the California Supreme Court has typically adopted a narrow construction of U.S. Supreme Court precedent. Thus, although the court has conceded that Nollan and Dolan apply to monetary exactions, ${ }^{288}$ it has held that if a local legislative body imposes fees by "set formula" rather than individualized discretion, the fees need not be roughly proportional to the impact of the proposed development. ${ }^{289}$ And in a case in which the state's coastal commission atissolutely prohibited development of a landowner's land, requiring two years of litigation before the landowner established that the commission had exceeded its authority, the court

285. CAL. CONST. art. I, $\S 19$ ("Private property may be taken or damaged for public use only when just compensation, ascertained by a jury unless waived, has first been paid to, or into court for, the owner.").

286. San Remo Hotel v. City and County of San Francisco, 41 P.3d 87, 100-01 (Cal. 2002) (indicating that the court has "construed the clauses congruently"); Santa Monica Beach, Ltd. v. Superior Court, 968 P.2d 993, 995 (Cal. 1999) (describing the state and federal constitutional provisions as "equivalent"); Hensler v. City of Glendale, 876 P.2d 1043, 1048 n.4 (Cai. 1994) (concluding that the analysis "applies equally" under state and federal provisions).

287. San Remo Hotel, 41 P.3d at 87. In San Remo Hotel, the plaintiff had explicitly reserved all federal claims, apparently in the hope of raising them in the potentially more hospitable environment of federal court, see supra text accompanying notes 178-181. The California Supreme Court, however, proceeded to analyze Nollan and Dolan as if they were expositions of California state constitutional law. San Remo Hotel, 41 P.3d at 101-02.

288. Ehrlich v. City of Culver City, 911 P.2d 429 (Cal. 1996). In Ehrlich, however, the city required the developer to pay a fee of $\$ 280,000$ as a condition for rezoning his property to permit a condominium project on a site that had previously housed a sports complex. Id. at 433 . The fee was designed to compensate the city for partial replacement of lost recreational facilities. Id. at 435. The California Supreme Court held that the fee was subject to analysis under Nollan and Dolan, but suggested that the city might be able to justify a fee if it could show that the process of rezoning other land to permit recreational development would involve significant costs. Id. at 449 .

Moreover, the Ehrlich court sustained another fee imposed on the developer-this one requiring payment of one percent of total building valuation (or donation of approved works of art of equivalent value) to the city art fund. The court held that "the art in public places fee is not a development exaction of the kind subject to the Nollan-Dolan takings analysis" because the fee was "a kind of aesthetic control well within the authority of the city to impose." Id. at 450 .

289. San Remo Hotel, 41 P.3d at 87 (sustaining the city's requirement that the developer pay a fee of $\$ 567,000$ for permission to convert a residential hotel to tourist use and holding that the fee is not subject to Nollan-Dolan analysis because it is determined according to a set formula rather than individualized determination); Ehrlich, 911 P.2d at 447, 450 (sustaining an art-inpublic-places fee of one percent of total building valuation and indicating that Nollan and Dolan apply "when a local government imposes special, discretionary permit conditions on development by individual property owners"). 
rejected the landowner's compensation claim, holding that when a development prohibition results from "an error by a government agency," the First English rule does not apply. ${ }^{290}$

California decisions, then, provide little evidence that state courts will police state and local land use regulations. At the same time, California's treatment of land use regulations has been consistent over several decades, so continuation of past practices is unlikely to disappoint investmentbacked expectations of landowners because investors should already have built in a significant discount to reflect the thin property protection provided by California law.

\section{b. New York}

Unlike the California Supreme Court, the New York Court of Appeals has demonstrated a willingness to invoke the Takings Clause to invalidate state and local regulation. Although the court has done so sparingly, ${ }^{291}$ the cases in which it has acted raise the traditional Takings Clause concern: singling out a small number of landowners to bear the cost of public benefits. ${ }^{292}$

In Seawall Associates v. City of New York, the New York Court of Appeals invalidated a five-year moratorium prohibiting landowners from demolishing or converting single-room occupancy (SRO) dwellings. ${ }^{293}$ The local law had also imposed on owners an affirmative obligation to rehabilitate such dwellings and to lease them at controlled rents ${ }^{294}$ and had conferred on the owner the right to purchase an exemption from the

290. Landgate, Inc. v. Cal. Coastal Comm'n, 953 P.2d 1188, 1197 (Cal. 1998).

291. For instance, the court held, in a trilogy of 1997 cases, that a landowner who acquires title after a regulation has been enacted may not challenge the regulation as a taking. See Soon Duck Kim v. City of New York, 681 N.E.2d 312 (N.Y. 1997); Gazza v. Dep't of Envtl. Conservation, 679 N.E.2d 1035 (N.Y. 1997); Anello v. Zoning Bd. of Appeals, 678 N.E.2d 870 (N.Y. 1997). The U.S. Supreme Court subsequently rejected that position in Palazzolo v. Rhode Island, 533 U.S. 606 (2001).

292. In addition to the Takings Clause, the court has also invoked substantive due process to protect landowners from actions by local zoning authorities. Thus, in Town of Orangetown $v$. Magee, 665 N.E.2d 1061 (N.Y. 1996), the landowner had purchased land zoned for industrial purposes for a price of $\$ 250,000$. Id . at $1064 \mathrm{n} .1$. After development plans were approved and the landowner had secured a permit for its industrial park, the landowner spent an additional $\$ 4,000,000$ in improvements before the town supervisor directed the building inspector to revoke the permit. $I d$. at 1064 . The town amended its zoning ordinance to prohibit commercial buildings on the subject land and then sought removal of a temporary building the landowner had constructed. When the landowner asserted a counterclaim seeking damages under $\$ 1983$, the trial court ordered reinstatement of the building permit and awarded more than $\$ 5,000,000$ in damages, concluding that the town's action had denied the landowner substantive due process of law. The court of appeals upheld the damages award. Id.

293. 542 N.E.2d 1059, 1072 (N.Y. 1989).

294. Id. at 1061. 
moratorium at a price of $\$ 45,000$ per unit. ${ }^{295}$ In holding the local law invalid both as a "physical taking" and a "regulatory taking," emphasized the change in city policy: For years, the city had encouraged demolition and redevelopment of SRO properties, ${ }^{297}$ and many of the current owners had purchased them for commercial development. ${ }^{298}$

Five years later, in Manocherian v. Lenox Hill Hospital, the court invalidated a state statute entitling not-for-profit hospitals to perpetual renewals, at controlled rents, of residential leases for hospital employees. ${ }^{299}$ Although drafted in general terms, the statute had been enacted at the behest of a single private hospital ${ }^{300}$ and imposed costs only on those landlords who had, at some time in the past, chosen to rent to that hospital. The court acknowledged New York's complex regulatory scheme for landlord-tenant relationships, ${ }^{301}$ but distinguished the challenged regulation, which affected only "a tiny number of dwelling units."

For present purposes, Seawall and Manocherian are important in two respects. First, they demonstrate that state courts can and do participate actively in policing both local and state regulations of land use. Second, they illustrate the dependence of takings claims on state law. Had city policy consistently been to encourage maintenance and rehabilitation of SRO properties, the landowners' takings claim in Seawall would have been far less attractive. And in Manocherian, the regulation at issue-which assured that there would never be vacancies in apartments leased by the hospital-might have been less objectionable if New York's regulatory scheme had not imbued vacancy with such significance by defining vacancy as the moment at which the landlord became entitled to a significant upward rent adjustment. ${ }^{303}$ Neither case presented a useful

295. Id.

296. Id. at 1065. The court invoked both the federal and state takings clauses to support its conclusion.

297. Id. at 1061.

298. Id. at 1067 (noting that the local law "totally prohibits the sole use-entirely permissible before the enactment of the law-for which investment properties are purchased: commercial development").

299. 643 N.E.2d 479 (N.Y. 1994). The majority opinion in Manocherian did not explicitly say whether its decision rested on the federal or the state constitution but consistently cited U.S. Supreme Court cases. The dissent characterized the case as one arising "under the Just Compensation Clause of the Fifth Amendment." Id. at 487 (Levine, J., dissenting).

300. The court cited legislative history indicating that the bill "ha[d] been introduced at the request of Lenox Hill Hospital in New York City" and that the bill's "purpose [wa]s to enable Lenox Hill to have the right to renewal leases." Id. at 481 (majority opinion) (internal quotation marks omitted).

301. Id. at 480-81 (detailing the statutory scheme).

302. Id. at 484 .

303. The dissenting judge in Manocherian emphasized that the challenged statute did provide for periodic fifteen percent increases in the hospital's rents and contended that these increases offset whatever losses landlords might otherwise suffer. Id. at 489 (Levine, J., dissenting). 
opportunity for the U.S. Supreme Court to offer nationwide guidance. And in both cases, state courts enjoyed a comparative advantage in understanding the regulatory background for the challenged enactment.

\section{c. Other States}

As already noted, many state courts have been reluctant to invoke federal takings doctrine to police local land use regulations because a conclusion that regulation amourts to a taking would, under First English, require the municipality to pay money damages to the aggrieved landowner. ${ }^{304}$ Because many of those states apply other doctrines to invalidate abusive regulations without imposing financial consequences on the offending municipality, the volume of successful takings claims understates the willingness of state courts to police the land use process.

Nevertheless, many state courts have invalidated local land use enactments as takings, even when those enactments did not fall afoul of any of the Supreme Court's per se rules. First, although many states, like California, construe their state takings clauses to be coextensive with the Takings Clause in the Federal Constitution, ${ }^{305}$ other states have construed their state constitutional prohibitions more broadly. ${ }^{306}$ For instance, in State ex rel. R.T.G., Inc. v. State, the Ohio Supreme Court held that a state designation of land as unsuitable for mining worked an unconstitutional taking, emphasizing the power of state courts to interpret their constitutions independently of the Federal Constitution. ${ }^{307}$ Moreover, the court emphasized that mineral rights are treated as separate property rights under Ohio property law, so that analysis under the state constitution appropriately focused on the regulation's effect on the coal rather than on the coal and surface rights as a package. ${ }^{308}$ The court's analysis, and its emphasis on the peculiarities of Ohio property law, reinforce the comparative advantage states enjoy in policing land use regulation.

Similarly, the Washington Supreme Court, in Manufactured Housing Communities $v$. State, held that its state takings clause provides landowners with broader protection than the parallel provision in the Federal Constitution. ${ }^{309}$ In holding unconstitutional a state statute giving mobile

304. See supra text accompanying note 281 .

305. See, e.g., Littman v. Gimello, 557 A.2d 314, 318 (N.J. 1989) (holding that "protections afforded under both constitutions are coextensive").

306. In some cases, state courts have concluded that the state takings clause provides broader protection than the federal one but held that the local regulation would constitute a taking under either provision. See, e.g., Whitehead Oil Co. v. City of Lincoln, 515 N.W.2d 401, 408-09 (Neb. 1994).

307. 780 N.E.2d 998,1008 (Ohio 2002).

308. Id.

309. 13 P.3d 183 (Wash. 2000). 
home tenants a right of first refusal to buy the park in which they live, the court concluded that the state constitution does not permit any taking of property for private use. ${ }^{310}$

In other cases, state supreme courts have found unconstitutional takings without distinguishing sharply between state and federal standards. Thus, in Purdie v. Attorney General, the New Hampshire Supreme Court held unconstitutional the state legislature's effort to redefine the high-water mark to reduce the rights of waterfront owners. ${ }^{311}$ Before reaching that conclusion, the court devoted considerable attention to the precise content of preexisting New Hampshire law, noting in particular the differences among state laws on this issue. ${ }^{312}$

R.T.G., Manufactured Housing, and Purdie all involved state statutes. But state supreme courts have been at least as active in invoking the Takings Clause to police local zoning authorities. Thus, state supreme courts have invoked takings provisions (state or federal) in favor of landowners who have been denied special permits, ${ }^{313}$ variances, ${ }^{314}$ and even zoning amendments. ${ }^{315}$

This brief discussion does not establish that state and federal takings clauses-as currently construed by state courts-adequately protect landowners against abusive regulation. But the state court experience to date does establish that state courts are institutionally capable of scrutinizing state and local land use regulations and that state courts in a number of states are prepared to invoke takings doctrine as a supplement to other state law doctrines that police the land use regulation process.

\section{CONCLUSION}

The Supreme Court's takings jurisprudence is not the incoherent muddle scholars often make it out to be. As a descriptive matter, the Court invalidates local land use regulations only when it can identify and apply a categorical rule that is not dependent on state law. Each of the categorical rules the Court has embraced reduces the incentive for state and local

310. Id. at $189-91$.

311. 732 A.2d 442 (N.H. 1999).

312. Id. at 444-47.

313. E.g., Eberle v. Dane County Bd. of Adjustment, 595 N.W.2d 730 (Wis. 1999) (invoking the state constitution and holding that a landowner who was denied a special permit stated a claim for damages under the state constitution).

314. E.g., Lischio v. Zoning Bd. of Review, 818 A.2d 685 (R.I. 2003) (concluding that a landowner denied a variance has suffered a regulatory taking, drawing no distinction between the state and federal constitutions, and providing no discussion of U.S. Supreme Court cases).

315. Henry County v. Tim Jones Props., 539 S.E.2d 167 (Ga. 2000) (holding that zoning classification constitutes a taking and that no distinction exists between the federal and state constitutions, and providing no discussion of U.S. Supreme Court cases). 
governments to single out particular landowners to bear costs not generated by their proposed use of land. Where the Court has not been able to identify a categorical rule that operates independently of state law, it determines the claim is not ripe or remands for application of a balancing test. The result is a delegation of takings issues to the state courts.

As a normative matter, the Supreme Court's approach is consistent with its institutional role in our federal system. First, the Court's limited intervention recognizes that property rights are the product of positive law created by the several states and preserves the freedom of the states to define and protect those rights. Second, by limiting itself to categorical rules that operate independently of state law, the Court applies its own resources to those cases in which it is most capable of providing useful guidance to other decisionmakers. Third, the Court's approach leaves to the states the primary responsibility for guarding against abuses in an area in which the states have more tools available to police effectively.

Have the states effectively policed regulatory abuses? On that question, reasonable minds will differ. State statutes and court decisions in virtually every state have constrained the local exercise of regulatory powers, but the constraints have undoubtedly been unsatisfactory to developers and property rights advocates. These advocates should recognize, however, that even if the Supreme Court were far more willing to invoke the Takings Clause to invalidate land use regulation, much of the policing would be left to the states (and, perhaps, the lower federal courts); the Court lacks the resources to systematically review state court decisions upholding local zoning and planning decisions. There is, however, a more important point. Ultimately, to the extent that the agenda of property rights advocates focuses on expanded Supreme Court involvement, that agenda is inconsistent with our federal system. The U.S. Constitution does not require a state to recognize any particular property right. If a state were foolish enough to allow development rights to be as uncertain as the spin of a roulette wheel, the state would violate no federal constitutional rights, so long as purchasers understood the rules of the development game. Democracy and competition among states provide the primary protection against inefficient property rights regimes; the Federal Constitution's Takings Clause protects only against changes in the rules of the game. 
